\title{
ARCHEOLOGIE O UHERSKÉM HRADIŠTI V DOBĚ VELKOMORAVSKÉ - VÝZKUMY, LIDÉ, POVODNĚ (40 LET OD ZAHÁJENÍ PLOŠNÝCH VÝZKUMŮ)
}

\author{
DRAHOMÍRA FROLÍKOVÁ-KALISZOVÁ
}

\begin{abstract}
Abstrakt: Před 40 lety byl zahájen první velký plošný výzkum na katastru Uherského Hradiště. Od té doby narůstá množství poznatků o vývoji osídleni nejdřive souostroví a později středověkého města s každým dalším sledováním liniových výkopů, nových staveb nebo přestaveb. Dodnes však středohradištní etapa zůstává ve stínu známějši staroměstské části celé veligradské aglomerace. Je to způsobeno zčásti existencí staroměstských pohřebišt's honosnou hrobovou výbavou, ale hlavně celou kaskádou nepřiznivých okolností, které uherskohradištské výzkumy provázely.
\end{abstract}

Klíčová slova: raný středověk - Uherské Hradiště - osidleni - pohřbívání-velkomoravská aglomerace.

Archaeology centred on Uherské Hradiště in the Great Moravian period-research, people, floods (forty years of blanket research)

\begin{abstract}
The first phase of blanket research in the Uherské Hradiště cadastral zone was launched forty years ago. Since then, the body of information about the development of the settlement, first a group of islands and later a medieval town, has grown with every newly observed line excavation, newly uncovered constructions and reconstructions. However, the Middle Hillfort phase has been overshadowed by the betterknown Staré Mésto area of the whole Veligrad agglomeration. The reason is the existence of Staré Město burial sites with luxury grave goods and, in particular, a series of unfortunate circumstances which have accompanied excavations in Uherské Hradiště.
\end{abstract}

Key words: early Middle Ages - Uherské Hradiště - settlement - burials - Great Moravian agglomeration.

\section{Př́rodní podmínky pro vznik staroměstsko-uherskohradišt’ské aglomerace}

Určujícím činitelem pro vznik a podobu osídlení v místech dnešních měst Uherského Hradiště a Starého Města byla poloha. Řeka Morava zde protéká mezi výběžky Chřibů na západě a Vizovických vrchů na východě a v pozdním pleistocénu vytvořila soustavu ostrovů na říčních štěrkopíscích, $v$ holocénu překrytých 2-6 m mocnými písčitojílovitými povodňovými hlínami, tzv. siltem, šedo-žluto-zelené barvy (Procházka-Havlíček 1996; Havlíček 1999). Až po přelomu letopočtu se na nich začaly vyvíjet půdy, růst vegetace a tvořily se podmínky umožňující jejich využití lidmi. Geologicko-pedologické zjištění doplnil pylový profil z geologické sondy na podloží ostrova na Mariánském náměstí (Svobodová 1990). Pro nejstarší uhlíkatou vrstvičku přímo na siltovém podloží jsou typické chrpy a sídlištní plevely, obé indikuje rozsáhlá pole v okolí. V následující náplavové vrstvě, silné přes $30 \mathrm{~cm}$, se odráží vývoj v delším časovém úseku: nejprve ubývá pylu pampelišky a přibývá pylu jitrocele a travin, jež značí spásání luk. Objevují se výtrusy kapradin a zároveň vzrůstá podíl olše, obojí vypovídá o vzrůstu vlhkosti. Nakonec se objevuje stulík, jehož př́ítomnost indikuje stojatou vodu. V další vrstvě bylo nalezeno malé množství pylových zrn, z nichž nejvyšší podíl patřil rodu Botrychium, což naznačuje zatravněné prostředí netknuté člověkem. V následující vrstvě černé subfosilní půdy, v hloubce $240-220 \mathrm{~cm}$, v níž mezi málo početným pylem dřevin převažovala vrba, vzrůstá podíl ostřic, mezi bylinami traviny a druhy čeledi složnokvětých (např. pampelišky) a merlíkovitých. Obojí patří mezi synantropní společenstva. Kromě slabého výskytu máku se neobjevují žádné indikátory lidské prrítomnosti. Teprve ve svrchní vrstvě se vyskytují doklady lidského hospodaření: pyly obilnin a úbytek pylů dřevin, travin, pelyňku a merlíkovitých. Stále však zůstává ostřice, nadále tedy byla půda podmáčená. Spektrum ukazuje na prostředí člověkem intenzivně osídlené, s porosty vrbin na okrajích ostrova. Tato horní část hnědočerné humózní vrstvy byla identifikována jako kulturní 


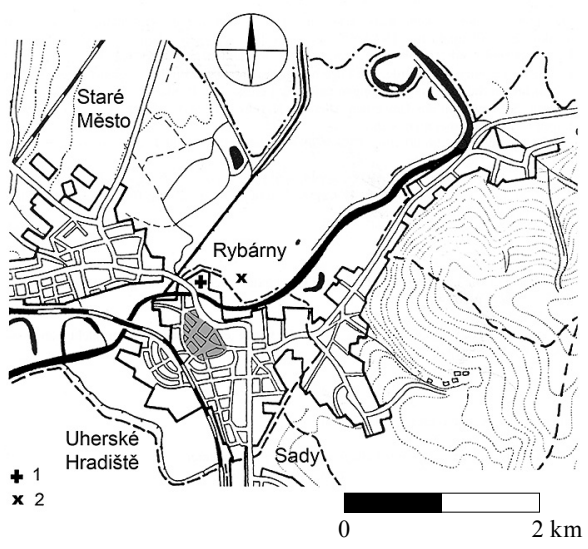

Obr. 1. Poloha svatojiřských ostrovů a čtvrti Rybárny. Lokality: 1 - Luční ulice; 2 - Bumbalov, šedě plocha svatojiřrských ostrovů, totožná s rozsahem stř̌edověkého až novověkého města Uherské Hradiště. Podle Menoušková-Vaškových 2005, Abb. 4, sestavila D. Frolíková.

Abb. 1. Lage der St. Georgsinseln und des Stadtviertels Rybárny. Fundstätte: 1 - Luění-Str.; 2 - Bumbalov, grau Fläche der St. Georgsinseln, identisch mit der Ausdehnung der Stadt Uherské Hradiště vom Mittelalter bis zur Neuzeit. Nach Menoušková-Vaškových 2005, Abb. 4, erstellt von D. Frolíková.

vrstva 9. století. Bohužel, tento pylový profil se nedá datovat $\mathrm{v}$ absolutních datech, zř́ejmě však zachycuje delší vývoj před 9. stoletím. Hypoteticky bychom snad mohli vrstvy nad podložím obsahující pyly z polí v okolí klást do doby římské, kdy zřejmě někde nablízku stála římská stanice, po níž máme nálezy cihel s kolky XV. legie ve Starém Městě (Galuška 1990, 132).

V prostoru dnešního Starého Města se Chřiby sklánějí pozvolným svahem až k řece, jejíž nivu bylo možno překonat po říčních ostrovech a pokračovat pak po jižním úpatí Sadské výšiny dál směrem na Slovensko (obr. 1). Místo obvyklé šířky $4 \mathrm{~km}$ zaplavované údolní nivy tak museli lidé překonat jen méně než 1 km (Culek-Ivan-Kirchner 1999, 211). Tato východozápadní trasa spojovala údolí Váhu přes průsmyky Bílých Karpat, podél říčky Olšavy do Pomoraví a na druhou stranu pokračovala přes Chřiby na Brněnsko a křižovala se zde se severojižní dálkovou cestou, tzv. jantarovou stezkou, tvořící spojnici mezi Podunajím a polskými nížinami. Je nepochybné, že strategická poloha místa byla důvodem, proč se nejdříve na terasách Starého Města, a nejpozději od konce 8 . století i na nízko položených ostrovech usídlovali lidé a proč se aglomerace, jež se zde během 9. století vyvinula, stala jedním z center Velké Moravy. Počet těchto ostrovů v 9. století je neznámý: R. Snášil píše o osídlení „na dvou sousedícich ostrovech uprostřed nejméně šestidilného souostrovi" $(1987,34)$, L. Galuška na pláncích ke svým článkům zobrazuje tři ostrovy (např. 2008, obr. 1; 2008a, obr. 1), avšak ještě na plánech barokní pevnosti Uherské Hradiště z roku 1676 (historická sbírka Slováckého muzea inv. č. 1424, fotokopie plánu Theophila Henela) je zakresleno vedle hlavního ostrova s městem obehnaným vodním příkopem a rozděleným tokem Rechly (Procházka 1999; v písemných pramenech uváděna jako mlýnský náhon, Mitáček-Procházka 2007, 71) dalších pět ostrovů různé velikosti a šestý zanikající, oddělený mrtvým ramenem (obr. 2). Na plánu z roku 1742 jsou již zachyceny jen dva ostrovy, přičemž město už není vodním tokem rozděleno (Hrubý 1957, obr. 1). Jak bylo zjištěno archeologickými výzkumy (na Otakarově ulici), byl původně vyšší počet ostrovů již v 9. století snižován postupným zanášením mrtvých moravních ramen a splýváním ostrovů.

\section{Historie bádání}

Zatímco na katastru Starého Města byly nalézány památky z doby velkomoravské (i pravěku) již od druhé poloviny 19. století díky činnosti místních učitelů Julia J. Christina (Christinův val), Františka Myklíka (Myklíkovo naleziště v poloze Špitálky) a dalších, Uherské Hradiště muselo na odkrytí své tisícileté minulosti ještě sto let čekat. Od 20. let 20. století se Staré Město stalo proslulou lokalitou zásluhou aktivity dalšího učitele Antonína Zelnitia, jež vyvrcholila záchranným výzkumem pohřebiště v Klečkově písečníku v poloze Na Valách v letech 1928-1932 pod patronací Státního archeologického ústavu v Praze a za spolupráce Lubora Niederleho. Na Zelnitiovu činnost navázali po druhé světové válce Vilém Hrubý (před válkou rovněž místní učitel) a Josef Poulík objevy velkomoravské zděné církevní architektury (Hrubý 1949; 1955; 1955a; Poulík 1955). První jmenovaný pokračoval dalšími výzkumy pohřebišt', kostelů i sídlišt' nejen ve 


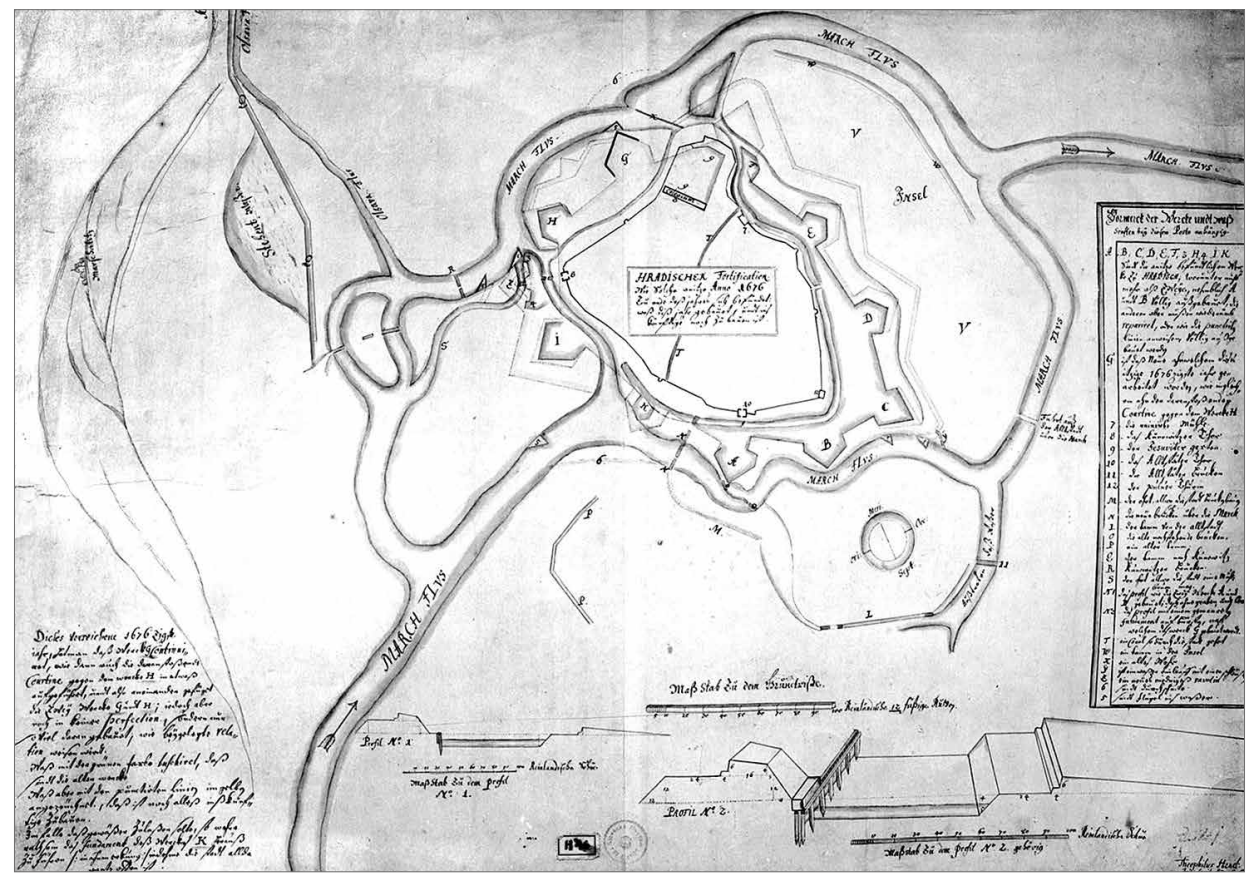

Obr. 2. Plán pevnosti Uherského Hradiště, 1676. Fotokopie plánu Theophila Henela, historická sbírka Slováckého muzea, inv. č. 1424. Dle dobové zvyklosti je plán situován severem dolů. Ve čtvrti Rybárny, poloha Bumbalov, je zakresleno plánované opevnění.

Abb. 2. Planskizze der Festung Uherské Hradiště. 1676. Fotokopie eines Plans von Theophil Henel, historische Sammlung des Museums der Mährischen Slowakei, Inv. Nr. 1424. Entsprechend dem Brauch der Zeit befindet sich Norden auf dem Plan unten. Im Stadtviertel Rybárny, Lage Bumbalov, ist eine geplante Befestigungsanlage eingezeichnet.

Starém Městě, ale i v jeho okolí a jako zaměstnanec Moravského muzea v Brně založil posléze pro tuto instituci detašované pracoviště ve Starém Městě. Jeho dvě monografie (Hrubý 1955a; 1965), publikující nálezy z doby Velké Moravy, spolu s jejich prezentací na výstavách, vynesly Starému Městu celosvětový věhlas. S V. Hrubým na výzkumech spolupracovaly postupně Věra Hochmanová-Vávrová a Kristina Marešová. Jeho nástupcem se stal v 80. letech 20. století Luděk Galuška (k historii staroměstských objevů podrobněji Menoušková 2020, 809-829).

Naproti tomu z území města Uherského Hradiště nebyly známy žádné nálezy starší než vrcholně středověké až do roku 1928. Byl to Karel Hanák (původně poštmistr, v letech 1935-1951 ředitel Slováckého muzea), jenž začal zachraňovat předměty ojediněle nalézané při bagrování při regulaci koryta řeky Moravy a při výkopech kanalizace ve městě. První nález z období Velké Moravy - třmen karolínského typu - zachránil v roce 1928, tedy ve stejném roce, ve kterém začal výzkum pohřebiště Na Valách ve Starém Městě. A zatímco staroměstské pohřebiště se brzy, i díky L. Niederlovi, stalo světoznámým, K. Hanák publikoval ojedinělé nálezy z Uherského Hradiště v místním Sborníku velehradském. Byly mezi nimi i dva zlacené gombíky z hrobu v Růžové ulici (obr. 3/R); jenže J. Böhm na základě svého kontrolního výkopu datoval tamní nejstarší kulturní vrstvu, v souladu s dobovými znalostmi, do 11. století (Hanák 1933, 5; Snášil-Procházka 1981, 12-13), takže nález zapadl. V roce 1943 při hloubení protileteckých krytů na dnešním Masarykově náměstí prozkoumal $\mathrm{K}$. Hanák část základů gotického kostela sv. Jiří se zazděným románským stavebním prvkem (Hanák 1947, 8; Menoušková 2013). Za zmínku stojí nález monoxylu v řece Moravě roku 1946 (trvale vystaven v Památníku Velké Moravy ve Starém Městě). Po smrti K. Hanáka zachraňovali archeologické nálezy Emanuel Lepka (taxikář) a nový ředitel muzea, historik umění Vilém Jůza. Na stavu poznání se mnoho nezměnilo ani dlouhá léta po nástupu 


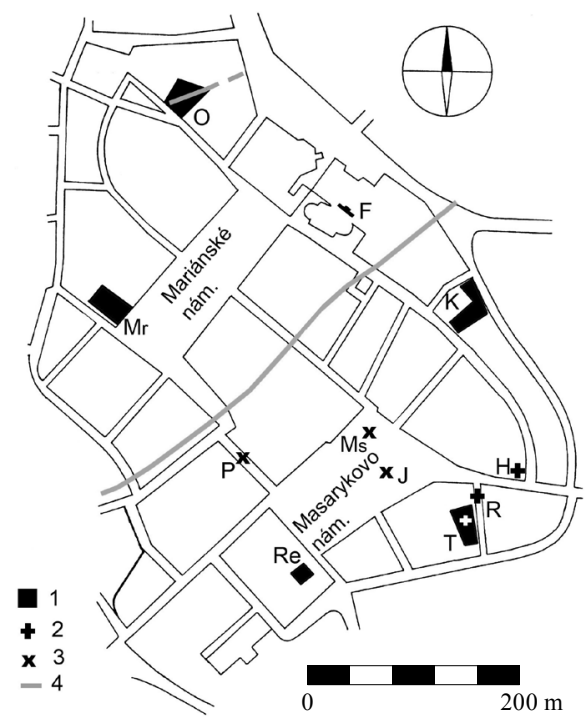

Obr. 3. Poloha lokalit a zaniklých vodotečí v Uherském Hradišti. Podklad Menoušková 2005, Abb. 4, sestavila D. Frolíková. 1 - zkoumané lokality; 2 - hroby; 3 - další situace zmíněné v textu; 4 -zaniklé vodoteče. Mr-Mariánské náměstí; O - Otakarova ulice; F - františkánský klášter; K - ulice Krátká - Inpost; H - Havlíčkova ulice; R - ulice Rủžová; T Telecom; Re - Reduta; J - kostel sv. Jiří; Ms - zdiva a malty u kašny a v jejím okolí na Masarykově náměstí; P - kameny na Protzkarově ulici.

Abb. 3. Lage der Fundstätten und verschwundenen Wasserläufe in Uherské Hradiště. Vorlage Menoušková 2005, Abb. 4, erstellt von D. Frolíková. 1 - untersuchte Fundstätten; 2 - Gräber; 3 - weitere im Text erwähnte Situationen; 4 - verschwundene Wasserläufe. Mr - Marienplatz; O - Otakarova-Str.; F - Franziskanerkloster; K - Straße Krátká - Inpost; H - Havlíčkova-Str.; R - Růžová-Str.; T Telecom; Re - Redoute; J - St. Georgskirche; Ms - Mauerwerke und Mörtel am Brunnen und in dessen Umgebung auf dem Masaryk-Platz; P - Steine in der Protzkarova-Str. prvního profesionálního archeologa - Roberta Snášila - do Slováckého muzea v roce 1961. Příčinou bylo to, že zakládací horizont středověkého města se nachází $200 \mathrm{~cm}$ hluboko pod dnešním povrchem, a do takových hloubek se tehdy nezasahovalo (s výjimkou specifické situace za války). Tak ještě v roce 1965 mohl V. Hrubý napsat, že ,ostrov před založením Hradiště nikdy nebyl intenzivněji osidlen" $(1965,100) .{ }^{1}$ Nebylo však pochyb o existenci dálkové cesty přes ostrovy, jejíž průběh hledal R. Snášil (1971; 1975).

Doslova převratná změna nastala před 40 lety v roce 1979 . Tehdy byla zjištěna středohradištní kulturní vrstva na nádvoří Galerie Slováckého muzea a vzápětí byla odkrývána při plošných předstihových výzkumech na Otakarově ulici a Mariánském náměstí (tehdy Rudé armády). Středohradištní vrstva byla zároveň zaznamenávána i při záchranných výzkumech a dokumentaci liniových výkopů na různých místech ve městě, místy i se zbytky zdiva nebo maltových ker (Snášil-Procházka 1984; Snášil-Novotný 1985; naposledy Menoušková 2013, 142-145). V roce 1986 odkryl R. Snášil při záchranném výzkumu hroby a zdivo z 9. století také ve čtvrti Rybárny, která dnes leží na pravém břehu Moravy a od Starého Města ji dělí Batův kanál, dřive rameno Vláka. Výsledky výzkumu byly publikovány včetně odborných analýz v sérii článků (Snášil-Kruta-Stloukal 1993; 1995; Snášil 2001). Nové objevy se bohužel staly municí $\mathrm{v}$ tehdejším soupeření o to, zda sídlem velkomoravských knížat i církve bylo

mikulčické hradiště nebo Staré Město-Veligrad, zosobněném J. Poulíkem a V. Hrubým. K tomu přistoupila rivalita mezi Starým Městem a Uherským Hradištěm, přenesená v archeologické rovině do rivality mezi Moravským a Slováckým muzeem, obdobně personifikované V. Hrubým a R. Snášilem. Více ideologickým než archeologickým sporům byla poplatná dobově podmíněná představa o prvotním osídlení severnějšího ze svatojiřských ostrovů již na počátku 8. století příchozími z mikulčického centra, jeho funkci „hradu“, časově následovaném osídlením ,předhradí“ na druhém ostrově a v Rybárnách a teprve následném vzniku hospodářského zázemí ve Starém Městě (Snášil 1987a). Dnes je především ilustrací tehdejších argumentačních „bojư“.

V 90. letech pokračovalo objevování velkomoravské minulosti svatojiřských ostrovů v rámci záchranných výzkumů, jež vedli Jiří Kohoutek, Rudolf Procházka, Petr Vitula, Martin Geisler, všichni z ÚAPP Brno, Peter Kováčik, z organizace Archaia Brno, R. Snášil a po něm Jiří Pavelčík,

\footnotetext{
1 Názvoslovná poznámka: V. Hrubý zavedl do literatury termín Svatojiřský ostrov (Hrubý 1957) pro označení polohy místa, na němž bylo v roce 1257 lokováno město, a ještě v prvním prríspěvku o tehdy nových objevech R. Snášil s R. Procházkou piší o ostrově sv. Jiří (Snášil-Procházka 1981). Při pozdějších archeologických výzkumech bylo opakovaně zjištěno, že šlo nejméně o ostrovy dva. Rozdělovala je vodoteč ve středověku zvaná Rechla, jež byla původně jedním z ramen Moravy a v novověku zanikla. Jelikož název Uherské Hradiště náleži až vrcholně středověkému městu a název ostrov sv. Jiří se v archeologické literatuře vžil, používám pojem svatojiřské ostrovy.
} 
oba ze Slováckého muzea. Tragickou událostí pro sbírkový fond archeologie byla povodeň v roce 1997, která zatopila depozitář, tehdy umístěný ve sklepích františkánského kláštera. S jejími následky se archeologické oddělení potýká dodnes.

Výzkumy po roce 2000 představují již současnost, nebot' je prováděli a provádějí současní archeologové Slováckého muzea a referuje o nich Dana Menoušková (2020, 809-829).

Plošné a sondážní výzkumy do roku 1999 a stav jejich zpracování2 (obr. 3)

a) Otakarova ulice - 1979-1983, 1985-1989

Výzkum provádělo Slovácké muzeum v Uherském Hradišti.

Vedoucí výzkumu: do roku 1987 R. Snášil, 1988 D. Kaliszová, 1989 technik V. Jírovský a dokumentátorka I. Kučerová bez odborného vedení rozebírali kontrolní bloky.

Vedení terénní dokumentace: 1979-1982 R. Procházka a R. Snášil, 1983 a 1985 R. Snášil a J. Novotný, 1986 R. Snášil, 1987 R. Snášil a D. Kaliszová, 1988 D. Kaliszová.

Nálezová zpráva: za roky 1979-1983 a 1989 není, za roky 1987-1988 D. Kaliszová (1989).

\section{b) Mariánské náměstí - 1980-1984}

Výzkum provádělo Slovácké muzeum v Uherském Hradišti.

Vedoucí výzkumu: R. Snášil.

Vedení terénní dokumentace: 1980-1982 R. Snášil a R. Procházka, 1983-1984 R. Snášil a J. Novotný.

Nálezová zpráva: není.

c) Nároží ulic Hradební, Františkánské a Krátké (Inpost) - 1993

Výzkum prováděl ÚAPP Brno.

Vedoucí výzkumu: M. Geisler a P. Vitula.

Vedení terénní dokumentace, nálezová zpráva: M. Geisler (1994).

d) Havlíčkova ulice č. 16 (di̊m manželi̊ Arnoštových) - 1993

Výzkum prováděl ÚAPP Brno.

Vedoucí výzkumu: P. Vitula.

Vedení terénní dokumentace, nálezová zpráva: P. Vitula (1994).

e) Nároží ulic Hradební a Růžová (Telecom) - 1993

Výzkum prováděl ÚAPP Brno.

Vedoucí výzkumu: J. Kohoutek a R. Procházka.

Vedení terénní dokumentace, nálezová zpráva: J. Kohoutek a R. Procházka (1993).

\section{f) Františkánská ulice (františkánský klášter) - 1991-1992}

Výzkum provádělo Slovácké muzeum v Uherském Hradišti.

Vedoucí výzkumu, vedení terénní dokumentace: R. Snášil.

Nálezová zpráva: není.

\section{g) Nároží ulice U Reduty a Komenského náměstí (nádvoří Reduty) - 1997}

Výzkum provádělo Slovácké muzeum v Uherském Hradišti a Archaia Brno.

Vedoucí výzkumu: J. Pavelčík za Slovácké muzeum a P. Kováčik za společnost Archaia.

Vedení terénní dokumentace, nálezová zpráva: J. Pavelčík a P. Kováčik (Kováčik 1997; Pavelčík 1997). 


\section{Současný stav zpracování a nálezů}

Poslední výzkum R. Snášila na Františkánské ulici nebyl zpracován ani do podoby nálezové zprávy, vyšla o něm jediná informace (Snášil 1992, 118-119) a v archeologickém oddělení Slováckého muzea se nacházejí pouze plány kláštera, terénní dokumentace výzkumu chybí. Výzkum na nádvoří Reduty byl zpracován a publikován pouze pro vrcholně středověkou etapu na části zkoumané společností Archaia (Kováčik, 1998), z části zkoumané Slováckým muzeem bylo publikováno určení botanického materiálu (Opravil 1998). Výsledky výzkumů ÚAPP v roce 1993 byly publikovány v časopise Výzkumy - Ausgrabungen 1993-1998 (Čižmář-Geislerová-Unger 2000, 234, 236; Geisler 2000, 59, 61) a v Přehledech výzkumů (Geisler 1997, 250; Kohoutek-Procházka 1997, 250-254; Vitula 1997, 254-255). Výzkum na ulici Hradební - Inpost byl publikován také v souvislosti s nálezem bronzového křížku (Frolíková-Kaliszová 2009). Zprávy o jednotlivých sezónách výzkumů na Mariánském náměstí a Otakarově ulici byly zpravidla publikovány formou zprávy v Přehledech výzkumů (Procházka-Snášil 1983, 62-64; Snášil-Procházka 1984, 63-65; Snášil-Novotný 1985, 71-74; Kaliszová 1990, 62-64; 1991, 50-51). Podrobného zpracování se dostalo zakládacímu horizontu středověkého města (Procházka-Snášil 1984; Procházka-Sulitková 1984). Objevům z velkomoravského období byly věnovány souhrnné články (Snášil-Procházka 1981; Snášil 1986; 1987; 1987a; Frolíková-Kaliszová 1990; 1991; 2001a; 2007; 2011) nebo tematické studie (Snášil 1984; Frolíková-Kaliszová 2001; 2002; 2003; 2004; 2009; 2009a; 2009b; 2011a). K celkovému zpracování středohradištního horizontu dosud nedošlo, a to z několika přičin. Některé koření již v metodě výzkumu, ${ }^{3}$ další v chybějící dokumentaci ${ }^{4}$ i nálezové zprávě, v neposlední řadě v zaplavení depozitářủ při povodni roku 1997, kdy byly rozmáčeny popisy celků na sáčcích i na celých krabicích, takže nálezy, které nebyly fyzicky očíslovány, nejsou identifikovatelné. Přesto jsem se pokusila o jejich zpracování. Výsledkem bylo zjištění, že až do zpř́istupnění dokumentace není možné pracovat s prvními pěti výzkumnými etapami z Otakarovy ulice (1979-1983, s výjimkou rekonstrukce podoby podloží), ale lze částečně interpretovat situace zejména staršího horizontu z Mariánského náměstí, přestože z každého nálezového celku (nálezy z jedné vrstvy v jednom čtverci nebo z jednoho objektu) chybí od jednotek kusů po stovky kusů. Problémem platným všeobecně je masivní narušení mladšího středohradištního horizontu nejstarším osídlením kolonizačního města, konstatované na všech zkoumaných polohách.

Všechny výzkumy zachycují shodné schéma vývoje osídlení svatojiřských ostrovů, v němž můžeme rozlišit dva hlavní horizonty: starší, kdy byly minimálně okraje ostrovů bud' pravidelně nebo aspoň často zaplavovány (lokality Otakarova, Hradební - Inpost i Hradební - Telecom), zatímco vnitřní plocha ostrova (Mariánské náměstí) se zdá být využívána hlavně jako výrobní areál; a mladší, kdy se plocha ostrovů rozšírila zasypáním mrtvých ramen odpadem a na povrchu ostrova vznikla kulturní vrstva mocnosti kolem $50 \mathrm{~cm}$, svědčící o intenzivním osídlení. O poloze Reduta, jejíž středohradištní fáze výzkumu zatím nebyla zpracována, víme, že celé souvrství mělo mocnost až 1 m (Kováčik 1999, 375). V nálezové zprávě jsou uváděny kontexty $260=261=204=205$ jako kulturní vrstva středohradištní s jedním objektem a kontext 259 jako nejmladší velkomoravská vrstva (Kováčik 1997). Nejasná je situace na Františkánské ulici: R. Snášil píše o jámovém objektu s množstvím střepů, ,z nichž menši část nese výrazné rysy předvelkomoravské keramiky“ (Snášil 1992, 118-119). Uvážíme-li polohu mimo střredověké městské hradby, mohlo by jít o odpadní areál staršího horizontu na okraji dalšího ostrova, odděleného týmž (mrtvým) ramenem, které bylo zkoumáno na Otakarově ulici; ${ }^{5}$ kdyby šlo o mladší horizont, byl by objekt dokladem rozšíření sídelního areálu po zanesení ramene a tím rozšíření sídlení plochy severozápadního ostrova. Pro druhou možnost svědčí skutečnost, že následuje již

\footnotetext{
3 Metoda výzkumu odpovídala tehdejšímu úzu - kopalo se po rýčových vrstvách, škrabkou a špachtlí byly preparovány pouze objekty typu ohništ', pecí, kamenných destrukcí, kůlových jamek, dřev apod.

4 Sešit s popisy terénních situaci 9. století na Otakarově ulici, označovaných jako vrstva III, z let 1979-1983 si ponechal R. Procházka, v muzeu není ani jeho kopie.

5 Jeho protilehlý břeh byl odkryt při dosud nepublikovaném výzkumu v roce 2017 (viz Menoušková 2020, 809-829).
} 
vrstva vrcholně středověká. S jednoznačnou interpretací je třeba vyčkat na budoucí zpracování výzkumu aspoň do podoby nálezové zprávy.

\section{Starší střredohradištní horizont}

Starší stř̌edohradištní horizont zahrnuje delší časové období, vymezené jen rámcově - stopy lidské prŕtomnosti se objevují asi od konce 8 . století. Na podloží tvořeném žlutozeleným siltem, místy s naplavenými šedými jíly, se začal tvořit půdní horizont a zřejmě současně i kulturní vrstva. Na Otakarově ulici jsme zkoumali okraj ostrova: napříč zkoumanou plochou, od východu k západu se táhlo příkopovité koryto, místy široké až pět metrů a hluboké kolem $50 \mathrm{~cm}$, vyplněné stojatou vodou (obr. 4). Patrně šlo již tehdy o mrtvé rameno nebo dokonce jen o jeho konec. Dno i svahy koryta - původní proudnice toku - od nivelety zhruba $175 \mathrm{~m} \mathrm{n}$. m. níže byly pokryty modrošedým zvodnělým slínem, usazujícím se ve stojatých vodách. Na slínu v nejhlubší části ležela deseticentimetrová vrstvička hutné zjílovatělé dřevité hnědé hmoty s vodorovným povrchem, tzv. hnilokal, vzniklý rozkladem dřeva za nepřístupu vzduchu. Často v něm byla ještě patrná vláknitá struktura dřeva a ležící kusy dřev i spodků do dna zaražených kůlů většinou malých průměrů (největší $20 \mathrm{~cm}$ ), uhlíky a střepy, mezi nimi často i velké kusy, z nichž se daly rekonstruovat části nádob. Výše bylo koryto téměř v celé své hloubce až $60 \mathrm{~cm}$ vyplněno černou hlínou protkanou vysráženými modrofialovými nitkami vivianitu $\mathrm{Fe}_{3}\left(\mathrm{PO}_{4}\right)_{2} \cdot 8 \mathrm{H}_{2} \mathrm{O}$, vznikajícího chemickou reakcí při rozkladu masitých zbytků na kostech. Co se týče nálezů, vedle zlomků keramiky všech velikostí byla vrstva doslova nabita zvířecími kostmi; vedle neopracovaného odpadu se objevovaly proplétáčky, šídla, zdobený parohový kotouček (Frolíková-Kaliszová 2002). Mezi kovovými nálezy vyniká předmět nalezený ve třech kusech R. Snášilem roku 1987. Byl jím tehdy interpretován jako sax, dokládající datování nejstarší vrstvy nejpozději do 8 . století (Zápis z komise k ukončení 8. sezony, uložený
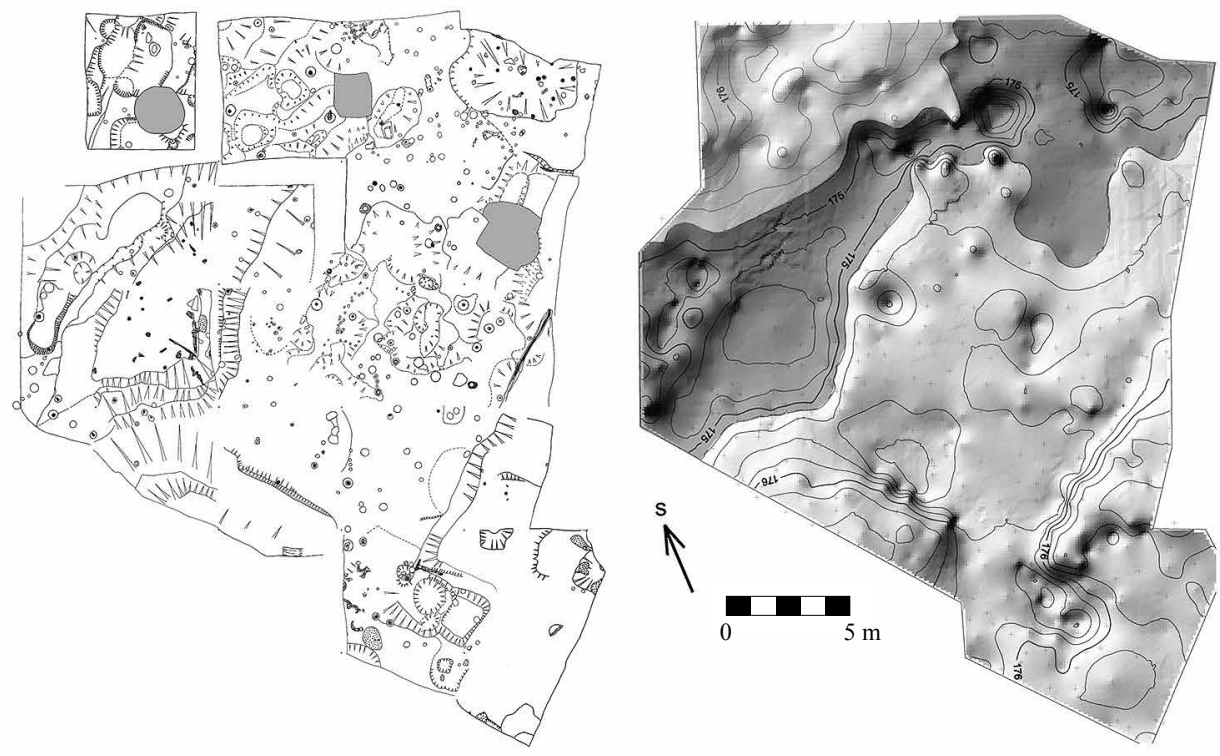

Obr. 4. Výzkum na Otakarově ulici, podloží. Vlevo terénní dokumentace, šedě vrcholně středověké studny, černě dřevo; vpravo počítačová modelace terénu v programu Surfer 7, autor M. Křemen, tmavě koryto vodního toku. Sestavila D. Frolíková.

Abb. 4. Grabung in der Otakarova-Str., Unterboden. Links Geländedokumentation, grau hochmittelalterliche Brunnen, schwarz Holz; rechts Computermodellierung des Geländes mit der Software Surfer 7, erstellt von M. Křemen, dunkel Flussbett. Erstellt von D. Frolíková. 


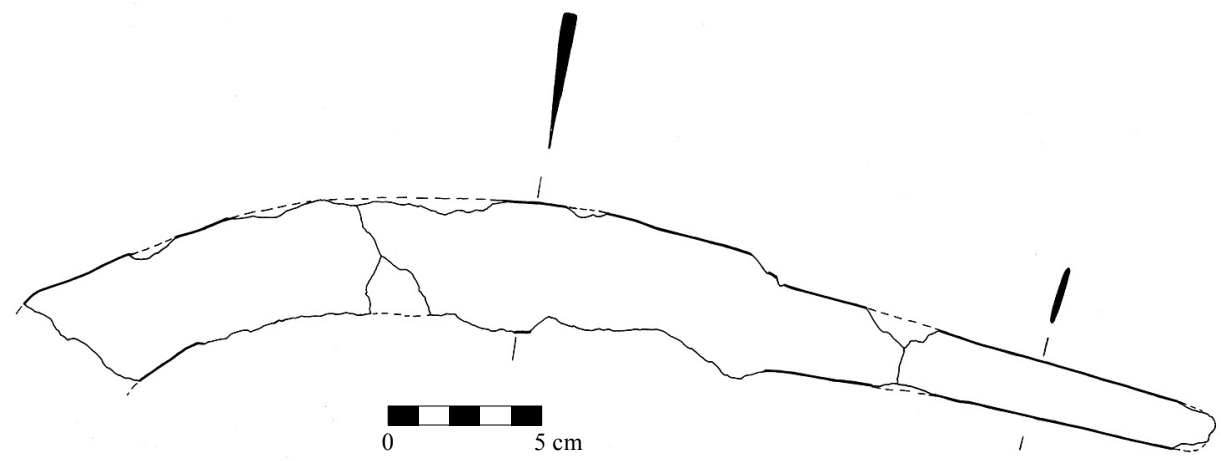

Obr. 5. Výzkum na Otakarově ulici, starší horizont, srpovitý zemědělský nástroj. Kresba D. Frolíková.

Abb. 5. Grabung in der Otakarova-Str., älterer Horizont, sichelartiges landwirtschaftliches Gerät. Zeichnung D. Frolíková.

v archeologickém oddělení Slováckého muzea). Při dohledávání sbírkových předmětů po povodních z roku 1997 jsem předmět našla a při jeho dokumentaci zjistila, že ve skutečnosti jde o mírně zahnutý pravděpodobně zemědělský nástroj neobvykle velkých rozměrů, k němuž jsem nenašla žádné př́ímé analogie (obr. 5). Rozhodujícím faktorem odlišujícím srpy od kos je způsob držení nástroje, který je určen nasazením čepele na trn, jenž v tomto př́ípadě odpovídá srpům. Vzhledem k délce zachované části $39 \mathrm{~cm}$ a šířce čepele $4,3 \mathrm{~cm}$ jsem uvažovala i o polokose, ty však mají trny krátké, zatímco tento nástroj má trn dlouhý, jak je obvyklé u srpů (Borzová 2016, 59-86). Torzo nástroje, jemuž chybí hrot, nejvíce připomíná mačetu. Vzhledem k jeho velikosti bych jeho využití viděla při sekání letniny z listnatých stromů a keřů.

Charakter výplně koryta svědčí o tom, že bylo využíváno jako smetiště. Při odkrytí první části koryta $\mathrm{v}$ roce 1981 byly četné kůlové jamky v něm interpretovány jako pozůstatky palisády v obranném př́íkopu (Snášil-Procházka 1981, 29; Procházka-Snášil 1983, 62-63; Snášil-Procházka 1984, 63; Snášil 1987, 36). Vzhledem k nemožnosti vysledovat jakoukoliv pravidelnost je však pravděpodobnější, že jde o pozůstatky kủlů nesoucích lávky a můstky přes bahnitou plochu, průběžně opravované a vyměňované (Frolíková-Kaliszová 1990, 119). Koryto proudnice bylo v ohybu lemováno agradační mělčinou, která na počátku osídlení ostrova byla zaplavována již jen za (pravidelných jarních?) povodní. Směrem do nitra ostrova byla tato plošina až $10 \mathrm{~m}$ široká, převyšovala dno koryta o $50 \mathrm{~cm}$. Na opačné straně koryta se břeh prudce zvedal. V mělké části ramene tvořil podloží tvrdý silt, na nějž nasedala přímo nejstarší kulturní vrstva o mocnosti $20-35 \mathrm{~cm}$. Z ní se do podloží opět zahlubovaly kůlové jamky, z nichž několik větších považoval R. Snášil za základ konstrukce dřevěné hlídkové věže, součásti palisádového opevnění (SnášilNovotný 1985, 71; Snášil 1986, 36). R. Procházka rovněž pokládal mělkou část říčního ramene za uměle sníženou plošinu a v interpretaci kůlů jako palisády v př́kopu souhlasil s R. Snášilem (Procházka 1990, 293), později od této interpretace ustoupil ve prospěch výkladu dřevěných kůlů jako ochrany proti vodní erozi, srovnatelné se situací v Mikulčicích (Procházka-Havlíček 1996, 209; Procházka 2009, 211). Rozhraním mezi terénem trvale pod vodou a úrovní občasných záplav je vrstevnice $175 \mathrm{~m} \mathrm{n}$. m, nad vrstevnicí $176 \mathrm{~m} \mathrm{n}$. m. ležel suchý střed ostrova umožňující osídlení. Ten byl však na Otakarově ulici zachycen jen malým výsekem, v němž byla řezem ověřena stratigrafie vrstev, nebot' původně byl považován za hliněný násep hradby (zápis z odborné komise k ukončení 8. etapy výzkumu v roce 1987). Na siltovém podloží a místy ještě na šedivém jílu ležela 30-40 cm mocná vrstva sterilních rezavohnědých jílovitých naplavenin s černohnědými 
povlaky vysráženého manganu. Rezavé zbarvení je způsobeno glejovými procesy, tedy stř́ídáním oxidačních a redukčních procesů při oxidaci železa při zvlhnutí půdy $\mathrm{v}$ zimě a jejím vyschnutí v létě. Na ní byla $10-20 \mathrm{~cm}$ silná vrstva šedohnědé jílovité hlíny s pískem a uhlíky - pohřbený půdní horizont, v němž dřevo karbonizovalo za nepřístupu vzduchu. Její povrch klesá z nejvyšší zachycené úrovně $176,50 \mathrm{~m} \mathrm{n}$. m. v jižním rohu zkoumané plochy, tj. nejdál do nitra ostrova. Tento půdní horizont, nikoliv kulturní vrstva, byl prevrstven až $60 \mathrm{~cm}$ mocnou vrstvou naplavenin (nikoliv jednorázových) ve spodní části jílovitých rezavohnědých, v horní písčitých žlutých. Leží již nad úrovní kolísající hladiny spodních vod a $\mathrm{v}$ jejich svrchních částech přibývalo humusové složky a objevovaly se ojedinělé střepy. Naplaveniny stejného charakteru překryly i smetištní vrstvu v bývalém mrtvém rameni Moravy a umožnily tak rozšiřit využívanou plochu. Na povrchu povodňového souvrství se vyrýsovaly objekty - ohniště s uhlíky a popelem. Lidskou rukou patrně vznikl pravoúhlý útvar o celkových rozměrech nejméně $500 \times 400 \mathrm{~cm}$, vkopaný do břehu ostrova (obr. 3, JV část plochy), s kůlovými jámami, ohništěm a sedmi kusy rohů praturů na podloží. Bohužel se tento útvar nachází na okraji zkoumané plochy, což znemožňuje jeho interpretaci.

Starší horizont osídlení v jádru západního ostrova byl prozkoumán na Mariánském náměstí, ${ }^{6}$ kde zůstal uchován ve výplních sídlištních jam (obr. 6), které se odlišovaly tmavší barvou od kulturní vrstvy mladšího horizontu. Nálezy dokládají činnost dílny nebo dílen zpracovávajících kosti, rohy a parohy, kovárny a dílny kovolijce. Významný podíl lovu ryb na výživě obyvatelstva dokládají nálezy rybářských háčků a rybích šupin. Odřezky, výrobní polotovary a kusy kostí, rohů a parohů se zářezy byly nalezeny v objektech $\mathrm{F}, \mathrm{G}, \mathrm{H}, \mathrm{K}, \mathrm{S}, \mathrm{V}, \mathrm{W}$, zvláště početné byly v objektech O (7 ks), U (14 ks) a M (20 ks). Hotové výrobky se objevovaly běžně, zejména šídla byla $v$ každém $z$ objektů staršího horizontu, většinou v počtu více kusů. Zmínku zaslouží píštalka z parohu a kost s otvory; po povodni se zachránila pouze píštalka, která byla vystavená v expozici Památníku Velké Moravy. Blízkost kovárny dokládá nález sedmi kusů kovářské strusky a kusů železa v objektu W, struska se objevovala i ve výplních dalších objektů. V objektu M se kromě pěti kusů strusky běžného ,železitého“ vzhledu nacházely i tři kusy strusky se sklovitým povrchem, které by mohly být vedlejším produktem metalurgie neželezných kovů. Kromě toho v něm byly nalezeny dvě bronzové ostruhy s háčky, z nichž jedna je neopracovaným výlitkem z formy, a železná ostruha s ulomenými konci ramen. Třetí bronzová ostruha pochází z objektu $\mathrm{P}$, v objektu $\mathrm{O}$ se našlo bronzové lité prolamované

6 Vrstvy i výplně objektů se kopaly po rýčových vrstvách ve čtvercích. Objekty byly vybírány vcelku, pokud byly hlubší než na jeden rýč, byla rozlišována horní a spodní část výplně.

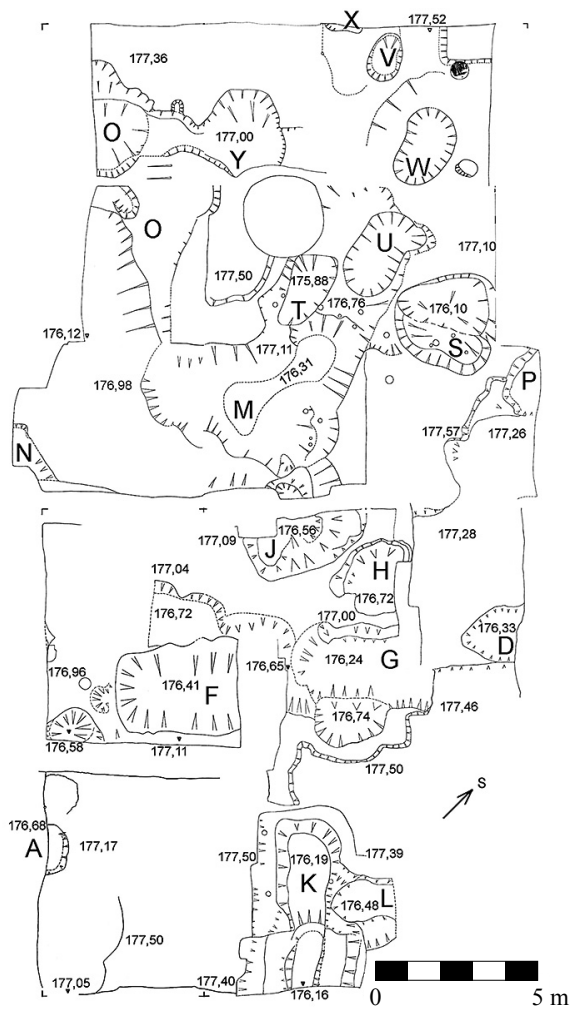

Obr. 6. Výzkum na Mariánském náměstí, starší horizont. Abb. 6. Grabung auf dem Marienplatz, älterer Horizont. Aus der Geländedokumentation erstellt von D. Frolíková. 


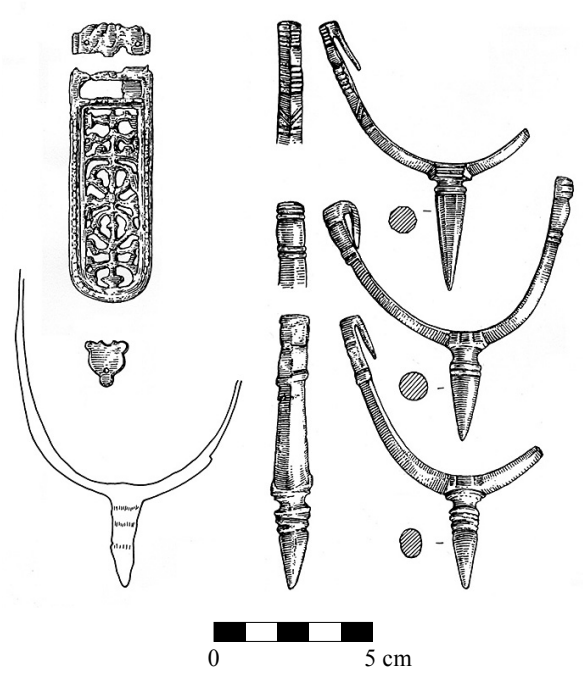

Obr. 7. Výzkum na Mariánském náměstí, starší horizont, ostruhy a avarsko-slovanská kování. Podle Poulík 1988 doplnila a upravila D. Frolíková.

Abb. 7. Grabung auf dem Marienplatz, älterer Horizont, Sporen und awaroslawische Beschläge. Nach Poulík 1988 ergänzt und bearbeitet von D. Frolíková. nákončí a v objektu S drobné bronzové kováníčko (obr. 7). Situace nasvědčuje tomu, že jámy byly součástí areálu kovolijecké dílny: všechny objekty $\mathrm{s}$ nálezy bronzů ležely v sousedících čtvercích. Lze souhlasit s R. Snášilem, že všechny tři ostruhy byly asi částmi skladu poškozených bronzových výrobků určených $\mathrm{k}$ přetavení, který byl při nějaké, zř̌ejmě násilné, události rozhozen (Snášil 1984, 156-158). Podle N. Profantové patří obě kování do pozdně avarského kulturního horizontu (Profantová 1992, 691-692). Také bronzové ostruhy s háčky zahnutými dovnitř jsou datovány před konec 8 . století (Profantová 1994, 67-68), proto byl celý starší horizont kladen do druhé poloviny 8. století (Poulík 1988, 198-203). Datování horizontu $\mathrm{s}$ tzv. avarskými bronzy v Mikulčicích do 8. století zpochybnil J. Zábojník: stejně jako mikulčické byly i uherskohradišt'ské ostruhy poškozeným polotovarem nebo to byly zlomky a opotřebené kusy, představují tedy spíše než doklad jejich místní výroby sklad z módy vyšlých věcí, které byly už jen surovinou určenou $\mathrm{k}$ přetavení. Podle něj se po pádu avarského kaganátu tamní řemeslníci přesunuli mimo jiné do nově se rozvíjejících center na Moravu a Nitransko, proto považuje tyto nálezy za datovatelné až do začátku 9. století (Zábojník 2005, 112). Pro Uherské Hradiště to v každém prrípadě znamená, že zde muselo již na přelomu 8. a 9. století existovat natolik významné centrum, že sem přicházeli (nebo byli přivedeni) kvalifikovaní řemeslníci z Karpatské kotliny. Otázkou, kdy byly ostruhy s háčky a garnitury opaskových kování pozdně avarského stylu nošeny, se v souvislosti s nálezy z celé staroměstsko-uherskohradišt'ské aglomerace zabýval také L. Galuška. Došel k závěru, že byly vyřazeny z používání v poslední třetině 8 . nebo až na přelomu 8. a 9. století (Galuška 2013, 91, 94).

Na východním ze svatojiřských ostrovů je starší horizont prozkoumán mnohem méně. Na ulici Hradební - výzkum Inpost se na jílovitém podloží v úrovni 176,33-176,64 m n. m. objevovaly ojedinělé kůlové jamky, překryté kulturní vrstvou staršího horizontu. Vedle jámových objektů byl v ní odkryt také neúplný půdorys polozemnice (Frolíková-Kaliszová 2009, 563-566). Vícenásobné povodňové naplaveniny byly zjištěny na Hradební ulici - Telecom, kde překrývaly nepravidelné jámy se slabou př́měsí uhlíků a ojedinělými nálezy hlavně zvířecích kostí. Autoři nálezové zprávy kladou projevy trvalého osídlení, prezentované ohništi, kůlovými i jinými jámami a humusovitou kulturní vrstvou, stř́íanou jílovitými náplavami, na přelom 8. a 9. století (Kohoutek-Procházka 1997, 252). Na ulici Havlíčkově výzkum nedosáhl podloží a starší středohradištní horizont tedy nebyl zkoumán.

Koryto mrtvého ramene na Otakarově ulici zanesly až $80 \mathrm{~cm}$ mocné povodňové vrstvy. Tím došlo ke spojení dvou dříve oddělených ostrovů. Tato událost je rozhraním mezi starším a mladším středohradištním horizontem, ovšem přesně nedatovaným. Dřívější koryto poté tvořilo proláklinu patrně se rozbahňující po každém dešti. Pravděpodobně kvůli lepší schůdnosti vznikl objekt 33 - rošt z trámů překrytý štěrkovým posypem (obr. 8). R. Snášil uvažoval o konstrukci jako o základu dřevohlinité hradby, v tom případě by však val musel být beze stopy snesen, nebo šlo o nedokončený záměr, navíc v podivné poloze pod vyvýšeným břehem ostrova 


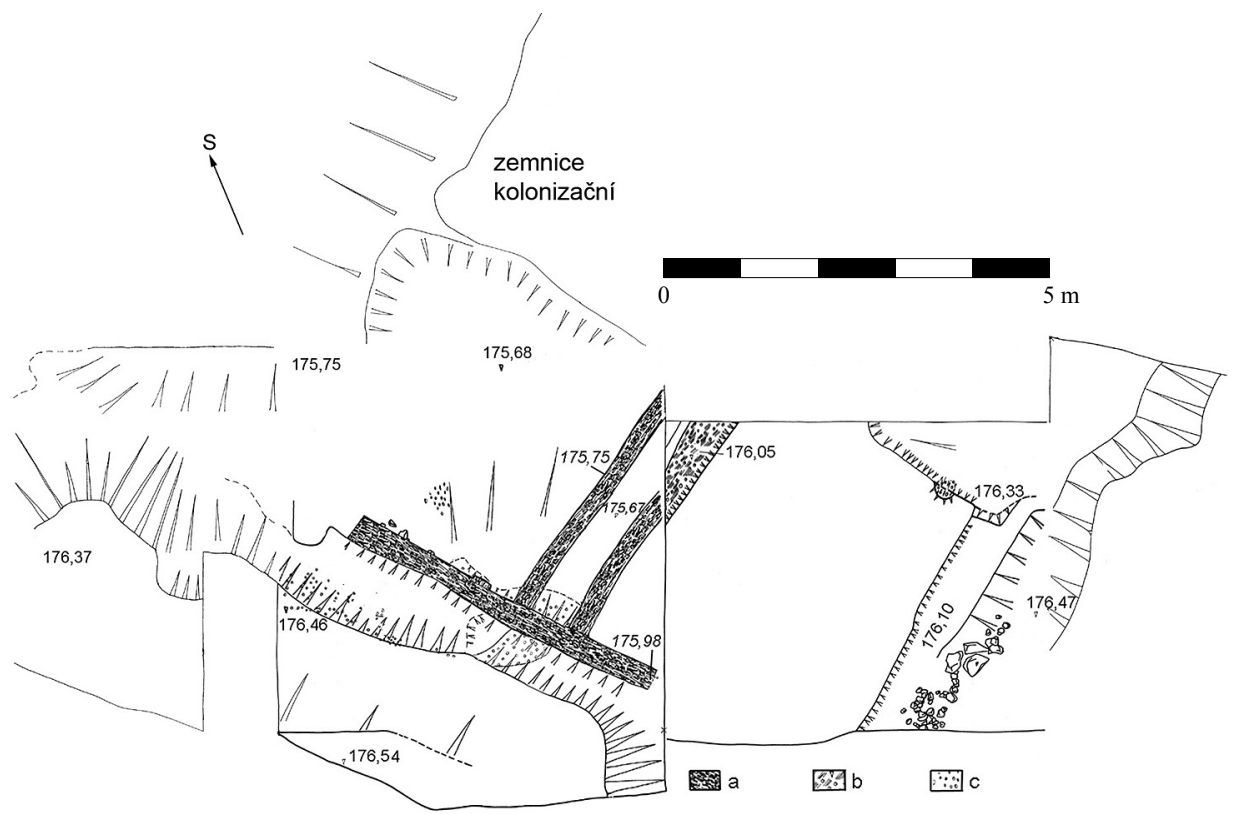

Obr. 8. Výzkum na Otakarově ulici, úpravy terénu v zaniklém říčním korytě po jeho zanesení velkou povodní. a -stopy dřevěných trámů; b - štěrkový posyp nad trámy; c - útržky štěrkového posypu. Podle terénní dokumentace upravila D. Frolíková.

Abb. 8. Grabung in der Otakarova-Str., Herrichtung des Geländes im untergegangenen Flussbett nach seiner Verschlammung durch Hochwasser. a - Spuren von Holzbalken; $b$-Schotterbelag über den Balken; $\mathbf{c}$ - Bruchstücke des Schotterbelags. Nach der Geländedokumentation bearbeitet von D. Frolíková.

(Snášil 1987, 36). Výklad funkce objektu ztěžuje také to, že neznáme jeho velikost.

\section{Mladší střredohradištní horizont - velkomoravský}

Na Otakarově ulici je kulturní vrstva mladšího horizontu charakterizována obsahem bílých zrníček vápna a malty, případně omítky, v tmavé hlíně. Kromě vyspělé keramiky byl objeven olověný křižek (obr. 9a; Frolíková-Kaliszová 2003) a zlomek dutého skla (Frolíková-Kaliszová 2009a). Nacházely se v ní objekty a ohniště, avšak při úpravách terénu během zakládání města po roce 1257 docházelo k jejímu narušování, masivnímu přemístování a místy odkopávání. $\mathrm{V}$ případě objektů jde nejčastěji o zahloubené jámy nebo jejich části, vesměs nezjištěného účelu, nebo o zbytky pecí, někdy i s předpecní jámou. Pozoruhodná je skutečnost, že v předpecní jámě kamenné pece 31/85 vyplněné popelem s úlomky malty se vyskytovaly také kousky vápence velikosti
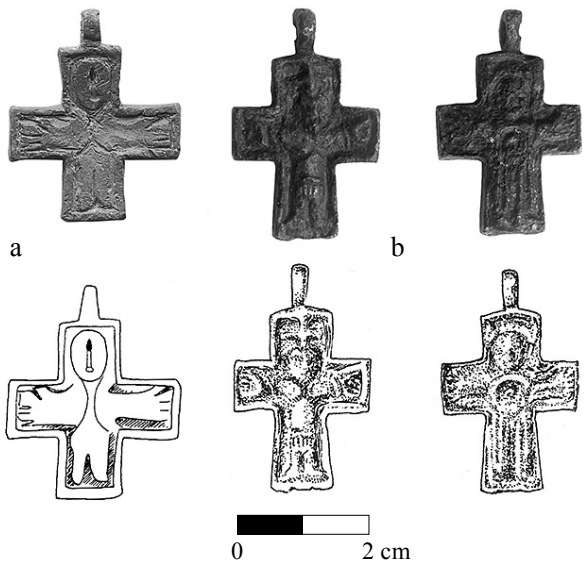

Obr. 9. Mladší horizont - velkomoravský: a - olověný kř́ižek z Otakarovy ulice; $b$ - bronzový kř́ižek z výzkumu na ulici Hradební/Krátká - Inpost. Kresba M. Housková, foto D. Frolíková.

Abb. 9. Jüngerer Horizont - großmährisch: a - Bleikreuz aus der Otakarova-Str.; b - Bronzekreuz von der Grabung an der Straßenecke Hradební/Krátká - Inpost. Zeichnung M. Housková, Foto D. Frolíková. 


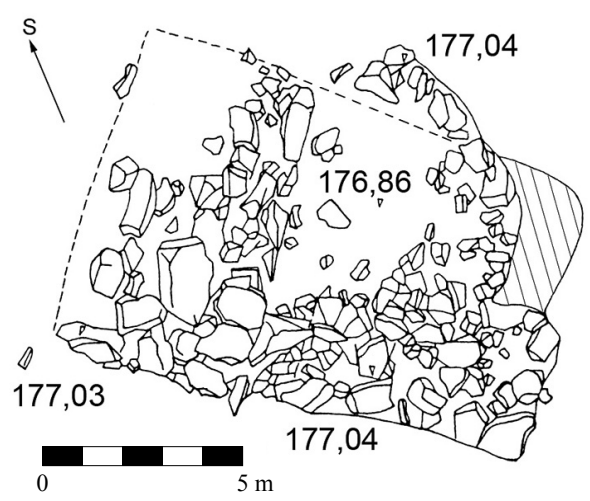

Obr. 10. Výzkum na Otakarově ulici, mladší horizont porušený stř̌edověkým městem - chlebová pec vložená do zahloubeného obdélného půdorysu s destruovaným zdivem pojeným maltou. Šrafovaně jílová výplň mezi obloukovou stěnou pece a zahloubeným půdorysem středohradištní stavby. Podle terénní dokumentace upravila D. Frolíková.

Abb. 10. Grabung in der Otakarová-Str., jüngerer, von der mittelalterlichen Stadt gestörter Horizont - in einem eingetieften rechteckigen Grundriss mit zerstörtem, mit Mörtel verbundenen Mauerwerk eingefügter Brotofen. Schraffiert Lehmverfüllung zwischen der gebogenen Ofenwand und dem eingetieften Grundriss des mittelburgwallzeitlichen Bauwerks. Nach der Geländedokumentation bearbeitet von D. Frolíková.
1-7 cm, z nichž některé byly přepálené do jemné mazlavé struktury, a mezi kameny z konstrukce pece se nacházely i dva velké kusy lité maltové podlahy, obrácené vyhlazenou stranou dolů. Kromě jam byla jako objekty označována také seskupení kamenů různých velikostí, většinou pískovců, z nichž některé na sobě mají přilepenou maltu a mnohé jsou přepálené. Evidentně se jedná o destrukce původně nadzemních nebo slabě zahloubených konstrukcí, což se týká zejména objektu 1/86 ze zdiva spojovaného maltou, které bylo kolonisty po roce 1257 využito pro konstrukci chlebové pece (obr. 10).

Na Mariánském náměstí byly v kulturní vrstvě mladšího horizontu, podobně jako na Otakarově ulici nalézány skrumáže kamenů, hrudky malty i kameny s nalepenou maltou, pocházející zřejmě z rozbořených pecí a základů nebo podezdívek staveb. Navíc zde byly nalezeny i zlomky ř́mských cihel a jeden zlomek střešní krytiny (po povodni nenalezeno). Rovněž 24 střepů $\mathrm{z}$ nádob tzv. antické tradice, $\mathrm{z}$ nichž některé se daly slepit, odlišuje mladší horizont od staršího. Nalezené železné předměty jsou většinou od povodní ztraceny; zachoval se zlomek železného kování vědra

ve tvaru vlaštovčího ocasu, zlomek bronzového držadla a zlomek bronzové tyčinky s očkem zdobené rytím, snad jehlice nebo zdobné jehly. Z obou velkých výzkumů na západním z ostrovů pocházejí nálezy skleněných korálků včetně polotovarů (Frolíková-Kaliszová 2011a). Velmi zajímavý výsledek přinesla analýza vzorků malt a omítek, provedená A. Zemanem. ${ }^{7} \mathrm{Na}$ vzorku malty s omítkou byla pozorována podkladová vrstva z bílé hrubozrnné malty, na níž byl nanesen nažloutlý nátěr o síle $0,2 \mathrm{~mm}$ a na něm místy zůstaly narůžověle hnědé plošky jako zbytky barevného nátěru. Úlomek vápence s vodorovnou bílou základnou měl vypouklou narůžovělou horní část, v níž byly zjištěny oxidy železa a fosforu; fosfor pochází z organického pojiva barvy, jíž byla natřena vápencová plastika. Analýza bílého prášku na střepu z nádoby vykázala opět přítomnost fosforu, oxidů železa a vápníku, jde zřejmě o zbytky po míchání nátěrové barvy.

Mladší horizont na Hradební - Inpost rovněž obsahoval sídlištní objekty - jámy, soustavy žlábků a kůlových jamek jako pozůstatky nadzemních staveb a ohniště. Zvláštní místo mezi nálezy zaujímá bronzový křŕžek (obr. 9b) s oboustranným plastickým vyobrazením: na aversu vidíme Krista na krŕžǐi oděného v kasuli s dlouhými rukávy a řasenou suknicí, na reversu Bohorodičku (Frolíková-Kaliszová 2009, 566-572). Zcela jiná situace byla zjišsěna v lokalitách Havličkova a Hradební ulice - Telecom. Na Havlíčkově ulici byla úroveň středohradištní kulturní vrstvy zachycena v sondách I a II (Vitula 1994). V sondě II svrchní část středohradištního souvrství (kontext 213=109) zabíral útvar, v nálezové zprávě označený jako kamenná destrukce, ohraničený v ploše sondy rovnou hranou (obr. 11 nahoře). Ve vrstvě byly vedle střepového materiálu nalezeny také kus malty, plochý kus červeného pískovce tloušt'ky $2 \mathrm{~cm} \mathrm{~s}$ maltou (podlahová dlaždice?) a zlomek tenké ploché šedé břidlice (stř̌šní krytina?). Protože mezi keramikou bylo

7 Vzorky byly nabroušeny a poté zkoumány v polarizačním mikroskopu JXA-50a v procházejícím a odraženém světle. Ve spojení s energiově disperzním spektrometrem EDAX PV9400 byly pořizeny snímky a provedena semikvantitativní analýza anorganické komponenty. Na vzorcích byla provedena měření v mikrosondách umístěných na 3-8 místech. Posudek A. Zemana je uložen v ARÚ Praha. 
i devět zlomků s obsahem tuhy ve hmotě, lze ukládání této vrstvy klást $\mathrm{s}$ velkou pravděpodobností až do 10 . století. Do vrstvy 214 pod ní, v hloubce $430 \mathrm{~cm}$ pod dnešním povrchem (176,62 m n. m.) byl uložen hrob, přesněji dolní polovina kostrového hrobu (obr. 11 dole). Podle antropologického určení J. Langové ${ }^{8}$ byl pohřbeným muž, zemřelý ve věku 35-45 let. Protože bylo dosaženo hloubky požadované stavbou, nebylo kopáno až na podloží.

Další hrob byl nalezen při výzkumu staveniště pro budovu Telecomu na nároží ulic Růžová a Hradební, ve vrstvě 193 ,sytě černého zbarveni", až $50 \mathrm{~cm}$ mocné, ze závěru velkomoravského osídlení (Kohoutek-Procházka 1997, 252). Oba tyto pohřby byly bez výbavy, avšak starší nálezy v ulici Růžové bez výbavy nebyly. Nejstarší byl nalezen již v roce 1931 v Růžové ulici před domem č. 158 U Labutě v hloubce pouhých $160 \mathrm{~cm}$. U silně poškozené kostry ležely dva gombíky z měděného zlaceného plechu s rytým ornamentem a zlatý úlomek (Hanák 1932, 7; 1933, 5). V. Hrubý nález popisuje jako dva gombíky, z nichž druhý byl navlečen na stř́brném kruhu hrozníčkovité náušnice (Hrubý 1957, 77). Později uvádí až sedm hrobů: „(...) pět hrobů, objevených r. 1931 v hloubce $160 \mathrm{~cm} v$ Hradebni ulici naproti domu č. 156, z nichž však byla prozkoumána pouze jedna ženská kostra. Byla vybavena dvěma poškozenými zlacenými gombíky, úlomkem zlatého předmětu dlouhým asi $4 \mathrm{~cm}$, a hradištni střepy. (...) Hrob ještě obsahoval rozpadlý pár stříbrných hrozníčkovitých náušnic a pár zlatých nebo zlacených, které později zmizely stejně jako zminěný zlatý fragment. (...) K. Hanák provlékl uchovaný kruh jedné Ag náušnice ouškem gombiku.“ (Hrubý 1965, 100). Rozpor mezi uváděnými počty hrobů vysvětluje R. Snášil tak, že v Růžové ulici byl v roce 1931 nalezen jediný hrob, popisovaný K. Hanákem, zmiňované dalši čtyři hroby bez nálezů byly odkryty až v roce 1943 při výzkumu základů kostela sv. Jiří na Masarykově náměstí a $\mathrm{V}$. Hrubý je později omylem přiřadil ke známému hrobu z Růžové ulice. Na základě rozboru zprávy K. Hanáka o výzkumu kostela sv. Jiří klade R. Snášil i tyto hroby do středohradištního horizontu osídlení a uvádí, že spolu s gombíky je v archeologické sbírce Slováckého muzea uloženo několik zlomků stříbrných hrozníčkovitých náušnic (SnášilProcházka 1981, 12, 33). V pozdějším soupisu lokalit uvádí D. Menoušková hrob z Růžové ulice se dvěma gombíky (Menoušková 2006, 100-101). Na lokalitě Hradební - Telecom bylo navíc nalezeno torzo zdiva o šířce $120 \mathrm{~cm}$, v základu pojeného hlínou a v nadzemní části maltou, o složitém půdorysu tvaru ramen kříže (obr. 12; Menoušková 2013, obr. 8, 9). Zdivo bylo zahloubené do výše zmíněné vrstvy 193, a nejen to - v základu se objevovaly i kameny s přilepenou maltou, které musely pocházet ze starší stavby (Kohoutek-Procházka 1997, 252). Mladší stavba po svém zániku byla patrně zdrojem kamenů, stavebních článků a krytiny, jež byly nalezeny při výzkumu na Havlíčkově ulici. Do mladšího horizontu nesporně náleží rovněž torza zdiv a maltových ker (obr. 3:Ms, J) objevená již v 80. letech při dokumentaci liniových výkopů na Mariánském i Masarykově náměstí (Snášil-Procházka 1984, 64; Snášil-Novotný 1985, 72-74; Menoušková 2013, 142; 2020, 809-829). Pozoruhodný kamenný zával (?) délky $8 \mathrm{~m}$, šířky nejméně $225 \mathrm{~cm}$ a síly $80-130 \mathrm{~cm}$

8 Za poskytnutí posudku děkuji jeho autorce PhDr. et RNDr. J. Langové. 


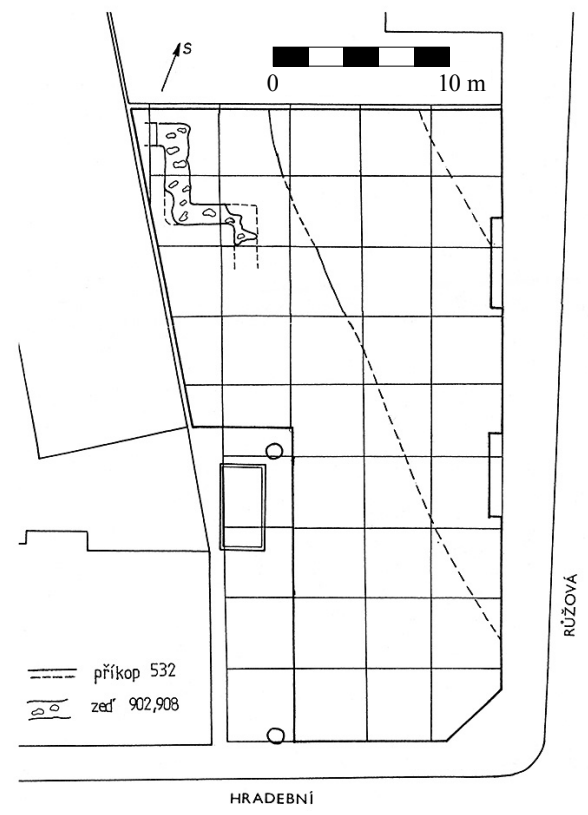

Obr. 12. Výzkum na nároží ulic Hradební a Rủžové - Telecom, objekty ve stř̌edohradištní vrstvě - zdivo a příkop. Podle Kohoutek-Procházka 1993.

Abb. 12. Grabung an der Straßenecke Hradební/Růžová Telecom, Objekte in der mittelburgwallzeitlichen Schicht Mauerwerk und Graben. Nach Kohoutek-Procházka 1993. se nacházel na Protzkarově ulici (obr. 3:P) pod středověkým souvrstvím, nad středohradištní vrstvou (Menoušková 2008a, 232-234). Nacházeli jsme v něm ojedinělé zlomky středohradištní keramiky. Jeho funkce není jasná (Menoušková-Dresler-Pelikán 2019); mohlo jít o zasypávání klesajícího bahnitého terénu kameny $\mathrm{z}$ nějaké zbořené stavby, čemuž by nasvědčovala poloha v blízkosti toku Rechly. Méně pravděpodobně se za dnešního stavu znalostí jeví úvaha o destrukci kamenného čela nedochované hradby.

\section{Pohřbívání na ostrovech v kontextu veligradské aglomerace}

Pohřebiště ve Starém Městě v poloze Na Valách bylo podle počtu nalezených a odhadovaného počtu zničených hrobů i své velké rozlohy centrálním pohřebištěm celé staroměstsko-uherskohradišt'ské aglomerace. Výše vyjmenované čtyři hroby však ukazují, že malé pohřebiště fungovalo i na východním svatojiřském ostrově, s největší pravděpodobností kolem kostela, zřejmě analogicky k pohřebištím kolem kostela v Modré (37 hrobů, Cibulka 1958, 43) či ve Starém Městě v poloze Špitálky (41 hrobů, Poulík 1955, 314-326; V. Hrubý uvádí hroby č. 1-56, Hrubý 1965, 397-398, obr. 41-42). Na mírně vyvýšené duně mezi potokem Salaškou, řekou Moravou a jejím ramenem Vláka stála také rotunda sv. Michala ve Starém Městě s 13 hroby (Hrubý 1965, 392-393). Př́íkladem hřbitova na málo vyvýšené duně v záplavovém území je kostel č. 7 - rotunda v Mikulčicích se 16 hroby kolem (Poulík 1975, 110). Stejnou písčitou dunou - ostrovem mezi rameny řeky Moravy - byla ve středověku poloha dnešní čtvrti Rybárny mezi Uherským Hradištěm a Starým Městem (obr. 1, 2). Její dnešní povrch, stejně jako města Uherského Hradiště, je zarovnán na úroveň kolem $180 \mathrm{~m} \mathrm{n}$. m. Ve výkopu jámy pro sklep v Luční ulici č. 12, v hloubce $235-243 \mathrm{~cm}$ pod dnešním povrchem prozkoumal R. Snášil v roce 1986 deset hrobů a torzo základového zdiva z lomového kamene pojeného nekvalitní béžovou maltou, dlouhé $6 \mathrm{~m}$ a široké $1,2 \mathrm{~m}$. Zed' probíhala směrem VSV-ZJZ, stejně byly orientovány hroby. Inventář u koster nalezený (nože, kostěný jehelníček s železnou jehlou, zlomky pásového kování rakví, zlomky středohradištní keramiky, zlomky ostruhy s ploténkami) pohřby jednoznačně řadí do 9. století (Snášil-Kruta-Stloukal 1993). Interpretace zdiva jako zbytku kostela je logická, R. Snášil kostel ztotožnil s předchůdcem špitální kaple sv. Klimenta na předhradí zmiňované v písemných pramenech od 14. století (Snášil 2001, 179-183). Pásová kování rakví svědčí o tom, že zde pohřbívali př́íslušníci elitní společenské vrstvy, šlo zřejmě o rodinný hřbitov vlastníka kostela a jeho lidí. Další hroby byly objeveny při výzkumu hradby v poloze Bumbalov na okraji Rybáren (Galuška 2006, 494-495); vzhledem k jejich poloze a k tomu, že předměty středohradištního stáŕí byly nalezeny pouze $\mathrm{v}$ jejich zásypu, však pokládám jejich dosavadní dataci za spornou (viz dále o hradbě).

V prostoru ulic Hradební, Havlíčkova a Růžová stál zřejmě kostel s malým rodinným hřbitovem. Nejasný v této souvislosti zůstává vztah k předlokační kapli sv. Jiří, která byla tradičně považována za stavbu původem velkomoravskou a hledána na Masarykově náměstí pod základy 
bývalého gotického kostela sv. Jiří, zbořeného v roce 1785 (Menoušková 2013, zde starší literatura). Geofyzikální měření ukázalo kruhovou anomálii pod presbytářem gotického chrámu, která však bez archeologického ověření zůstává v rovině hypotetického ztotožnění se sakrální stavbou, snad rotundou, z 9. století (Dresler-Vágner 2013).

\section{Nové poznatky prŕírodních věd k životu na svatojiřských ostrovech}

Pylová analýza profilu z výzkumu na Otakarově ulici (Svitavská-Svobodová 2011) nepřekvapivě ukázala trvalou př́tomnost vlhkomilných dřevin, což je na ostrově přirozené, jakož i porosty dubových habřin v okolí. Bylinný porost samotného ostrova tvořila rumištní trávo-bylinná synantropní vegetace. Ochmet dokládá teplejší oceánické klima. Rozvinuté obilné zemědělství v okolí je doloženo pylem pšenice a žita a plevely chrpou, vlčím mákem a svlačcem rolním. Játrovka hlevík tečkovaný, halucha vodní, lekníny a orobince dokládají odkrytou zamokřenou ladem ležící půdu v blízkosti stojaté vody, což odpovídá mrtvému rameni. Pohyb hovězího dobytka na lokalitě indikuje velké množství hyf houby Sporormiella, která roste na zvířecích exkrementech. Jitrocel kopinatý také dokládá pastvu, minimálně ve starším horizontu se zřejmě mezi řídkou zástavbou pásl dobytek. Ve svrchních vrstvách staršího horizontu se vyskytují vodní zelené řasy, které mohou osídlovat malé tůn̆ky. Ostatně řeka Morava vytvářela tůn̆ky se stojatou vodou a mrtvá ramena až do své regulace ve 20. století. Rovněž máta roste na vlhčích stanovištích. Zajímavý je v tomto kontextu kvetoucí břečt’an, který kvete vysloveně jen na dlouhodobě osluněných polohách. K časově a civilizačně zajímavým patří nález pylu ořešáku, který se na naše území dostal v době římské a spolu s pylem révy vinné ze staršího horizontu dokládá pěstování kulturních plodin přjatých ze Středomoří, patrně spíše na svazích v okolí. $Z$ druhů, které mohly mít větší význam, je třeba zmínit pohanku, jejíž pěstování se donedávna datovalo až od novověku. Pohanka byla mezi pyly nalézanými jak ve vzorcích z Mikulčic, tak z Pohanska (Svobodová 1990, 200-202). Později vzrůstá podíl pelyňku a merlíkovitých rostlin jako dokladů polního hospodářství, zřejmě spíše charakteru zahrádek u domů na ostrově, jehož okraje však zůstávaly bažinaté. Následující tenká povodňová vrstva datovaná před kolonizační horizont složení pylového spektra neposkytla.

Z výzkumů v Uherském Hradišti byly donedávna zpracovány pouze zvířecí kosti ze sezony 1987 na Otakarově ulici Z. Kratochvílem z AÚ ČSAV Brno. V rámci grantu GAČR Sídelní aglomerace velkomoravských mocenských center v proměnách údolní nivy řešitele L. Poláčka byly osteologicky určeny kosti identifikované po povodni z výzkumných sezon 1985-1988 na Otakarově ulici v Uherském Hradišti. Analýzu provedl V. Páral z Veterinární fakulty Masarykovy univerzity v Brně a srovnání obou poskytlo mimo jiné názornou ukázku povodňových ztrát na sbírkovém fondu (Frolíková-Kaliszová 2004). Z výsledků osteologické analýzy vyplynulo, že nejvíce (kolem $50 \%$ ) kostí pochází z prasat, následuje tur domácí, o něco méně jsou zastoupeni drobní přežvýkavci. $V$ přepočtu na množství získaného masa jsou ovšem vepřové a hovězí srovnatelné, zatímco podíl koz a ovcí byl výrazně menší. Z hlediska výživy obyvatel stravou živočišného původu nejsou mezi starším a mladším sídelním horizontem podstatné rozdíly. U drůbežích kostí je situace složitější, vzhledem k jejich křehkosti se zachovaly jen vzácně a spíše náhodou, jejich počet tedy nemůže být určující pro stanovení množství zkonzumovaných kusů. Vypovídají jen o tom, že slepice a husy byly chovány. Převaha kostí vepře domácího nad turem byla zjištěna ve velmožském dvorci na Pohansku (Kratochvíl 1992) nebo na hradišti v Mikulčicích (Chrzanowska-Krupska 2003; Chrzanowska-Januszkiewicz-Zalęcka 2003) a také na hradišti Pobedim (Bialeková 1988, 301-303). Z. Kratochvíl tuto skutečnost pokládá za projev preference vepřového masa před hovězím v prostředí vyšší společenské vrstvy, zatímco na venkovských sídlištích je obvyklá převaha kostí skotu nebo jejich vyrovnaný poměr (Dreslerová-Hajnalová-Macháček 2013). Na prrítomnost společenské elity na svatojiřských ostrovech jasně ukazují vedle kostí běžné lovné zvěře - srnčí, jelení, praturů i medvěda - hojná jelení paroží (21 ks ve starším horizontu, v mladším už jen $4 \mathrm{ks}$ ) a zejména impozantní rohy divokých praturů o průměru $15 \mathrm{~cm}$ u kořene a délce jednoho $70-80 \mathrm{~cm}$ (13 ks ze staršího horizontu, k tomu lebka i s rohy, 5 ks z mladšího horizontu). 
Podle perlení paroží pocházelo z jelenů z lužních i horských lesů, a to z ulovených zvířat, nikoliv ze sběrů shozených parohů (na základě informace Z. Kratochvíla uvádí Snášil 1983, 153). Zároveň úbytek jejich počtu v mladším horizontu ukazuje na odlesňování krajiny, vynucené spotřebou dřeva při rozrůstání se celé aglomerace (Culek-Ivan-Kirchner 1999, 215-2016). Je nepochybné, že tuto zvěř si pro sebe a svou družinu vyhrazoval kníže, a je jisté, že lovy velkomoravských knížat pratury alespoň na Uherskohradišt'sku dovedly k vyhubení, protože podle Z. Kratochvíla jde o jedny z nejmladších nálezů praturů na Moravě (Frolíková-Kaliszová 1991, 37-38; 2004, 78).

\section{Otázka opevnění}

Na svatojiřských ostrovech dosud nebylo nalezeno opevnění. Jako pozůstatky opevnění byly dříve vykládány dvě archeologické situace. První z nich byla nalezena v roce 1980 na jihovýchodním konci Hradební ulice poblíž Reduty v hloubce $510 \mathrm{~cm}$ pod dnešním povrchem. Při výzkumu byly odkryty dvě řady kůlů se seřezanými hroty, řazených vedle sebe do hrotitého dna paralelních žlabů, jinak bez nálezů. Jedna řada směřovala od okraje ostrova do jeho nitra, druhá linie byla kolmá k první a sledovala obvod ostrova zcela mimo osídlenou plochu (až do 20. století). Kůly první řady stály těsně vedle sebe, měly menši průměry a kulatý průřez, mohutné kůly druhé řady měly rozestup 160-190 cm, některé byly opracovány do čtvercového až obdélného průřezu a z vnitřní strany $\mathrm{k}$ nim přiléhala vodorovně kladená kulatina a půlkulatina, zachovaná ve třech řadách nad sebou (Snášil-Procházka 1981, 27, tab. III). Z kủlů byl odebrán vzorek na analýzu C14, která přinesla podivuhodné datum $650 \pm 130$ (Snášil 1987, 35). Proto byly pokládány za opevnění ostrova z doby předvelkomoravské, „nejpozději koncem 70. let 8. stol.“ (Snášil 1987a, 149). R. Procházka později uvádí, že obě řady spolu navzájem nesouvisejí, přičemž kůly, z nichž bylo radiokarbonové datum získáno, jsou právě ty, které směřují kolmo na linii břehu, a připouští jejich původ kdykoliv před stavbou barokní fortifikace v nadloží (Procházka 2009, 212). L. Galuška (2008a, 116-120) palisádu po obvodu ostrova klade do vrcholného středověku a pokládá ji za zpevnění ŕíčního břehu, zatímco u kůlů směřujících do nitra ostrova v souladu s radiokarbonovým datem připouští jejich původ ještě před trvalým osídlením ostrova. Masivní zahrocené dřevěné kůly byly nalézány při výzkumech v 90. letech J. Pavelčíkem a R. Procházkou na Zelném trhu a v letech 2006-2007 na Protzkarově ulici D. Menouškovou. Zatímco starší nálezy byly ztraceny po povodních 1997, mladší nálezy byly dendrologicky datovány, s výslednými daty 1187, 1227 a 1317-1318 (Menoušková 2008a, obr. 6). Na základě nových dendrodat kůlů, jejichž vzhled a způsob opracování podle dokumentace nápadně připomínají kůly z palisády nalezené v roce 1980, jakož i novějších nálezů z prostoru ulice U Reduty a Komenského náměstí, dendrologicky rámcově datovaných k polovině 15. století, se D. Menoušková přiklání k datování systému dřevěné obvodové palisády předsunuté před gotickou hradbu nejdříve do 15. století (Menoušková 2008, 451). Ani na jednom z ostrovů, na nichž bylo město roku 1257 Přemyslem Otakarem II. založeno, nebylo zatím nalezeno nic, co by mohlo být bez pochybností vykládáno jako opevnění. Nejbližší opevněnou polohou jsou Rybárny s hradbou v poloze Bumbalov. Byla zkoumána V. Hrubým a K. Marešovou v letech 1977-1979 metodou zjišt’ovacích sond. R. Procházka ji rekonstruoval jako hradbu $\mathrm{s}$ kamennou plentou a dřevohlinitým tělesem s vnitřní konstrukcí kombinující kleštiny a komory (Procházka 1990, 293, 296). Podrobně bylo toto opevnění publikováno L. Galuškou (2006), terénní situace pouze se třemi hroby pod původní úrovní terénu, jedním na úrovni a dvěma v tělese hradebního náspu však budí rozpaky. Vzhledem k tomu, že na plánu barokní pevnosti je na Bumbalově vidět jakési ohrazení (obr. 2), patrně k ochraně cesty z Uherského Hradiště do Starého Města, kladu tímto otázku: nešlo o složitější vývoj, kdy byl ještě viditelný val využit pro barokní fortifikaci, a alespoň hroby v tělese hradby nebyly uloženy v mezidobí? Časové rozpětí staletí by vysvětlovalo jak ohniště, tak povodňové vrstvy i to, proč se kamenná hradba nepropadala do zásypu hrobu 1 . Otázku by mohl zodpovědět revizní výzkum, pokud (dokud) není místo zastavěno. Druhým zdrojem rozpaků je umístění fortifikace. Př́ipadný útok v tomto místě musel směřovat od severu, resp. severovýchodu, tedy z hlubokého vnitrozemí. Pravděpodobné vysvětlení L. Galuška 
našel v událostech bojů mezi bratry Svatoplukem II. a Mojmírem II.; s tím souhlasí i datování vzniku hradby do doby největšího rozmachu zdejší aglomerace ve druhé polovině nebo dokonce až ke konci 9. století (Galuška 2006, 503, 507). K umístění hradby lze dodat, že po nálezu kostela s pohřebištěm ve čtvrti Rybárny je velmi pravděpodobné, že zde stálo sídlo velmože - dvorec $\mathrm{s}$ vlastnickým kostelem, a to mohlo být důvodem nebo jedním z důvodů výstavby ochranné hradby na ostrově, který byl na dalších stranách chráněn osídlením na sousedních ostrovech. Na druhé straně nález mohutné hradby v místech relativně přirozeně chráněných jen zesiluje otázku po ochraně jižněji vysunutých ostrovů v místech pozdějšího města Uherského Hradiště.

Lehčí konstrukce opevnění Starého Města oproti Mikulčicím a z toho plynoucí jeho nižší obranyschopnost vyvolává v R. Procházkovi představu o urychlené a možná nedokončené výstavbě v době před pádem velkomoravské říše (Procházka 2009, 222), což v zásadě souhlasí s vysvětlením L. Galušky. Považuji za možné, že předtím celá aglomerace neměla těžké opevnění, protože ležela ve vnitrozemí chráněném před útoky bavorských a franských vojsk pevnostmi Pohansko a Mikulčice. Doba konsolidace po útěku Svatopluka II. byla př́liš krátká na to, aby byl celý systém opevnění dokončen, a po rozpadu centrální moci po roce 906 už nebylo nikoho, kdo by měl dost moci a sil stavbu zorganizovat.

\section{Závěr}

Pro budoucí bádání je hlavním úkolem (za samozřejmého předpokladu zpracování starých výzkumů) vyřešit datování předělu mezi starším a mladším horizontem. Problémem je, že neexistují dendrodata, protože nalezená dřeva byla většinou malých průměrů a navíc pocházejí vesměs z dřevin luhu s rychlým př́růstkem hmoty a širokými letokruhy, takže ani to největší (z Otakarovy ulice) jich nemělo dostatečný počet. K tomu přistoupil důsledek povodně 1997, po níž byla při přesunech nálezového fondu všechna dřeva ztracena. Zůstává jen relativně chronologické datování vycházející ze zkoumání keramiky (Frolíková-Kaliszová 2001). Mladší horizont se zděnými stavbami je tak na základě znalosti historického vývoje kladen do doby rozkvětu Velké Moravy, rámcově do druhé poloviny 9. století až počátku 10. století. Rovněž konec osídlení není datován, zřejmě postupně vyznívalo během první čtvrtiny? třetiny? poloviny? 10. století. Sporadické nálezy tuhové keramiky a bronzový křížek naznačují skrovnou lidskou přítomnost na ostrovech i v mladohradištním období. Nesporná je pouze skutečnost, že kulturní vrstva se měnila v půdu a ta byla po založení města roku 1257 zase přeměněna na kulturní vrstvu, s ničivými důsledky pro pozůstatky staveb.

Objevy zdiva doprovázeného hroby, které zřejmě znamenají existenci malých vlastnických kostelů s rodinným hřbitovem uvnitř dvorce velmože nebo př́slušníka knížecí rodiny, ruší dřivější představu veligradské aglomerace jako místa organizovaného zásadně odlišně od mikulčické aglomerace. Tato představa sice nikdy nebyla explicitně vyjádřena, ale vyplývá z optického dojmu z tradičního kartografického zobrazení - velký celek Starého Města, malý ostrůvek svatojiřský a opodál sadská výšina. Hlavní rozdíl mezi oběma centrálními aglomeracemi spočívá v jiné terénní konfiguraci a jí daných podmínkách: zatímco mikulčická akropole ležela na ostrově, na kterém se nacházela velká bazilika spolu s knížecím palácem, a byla obklopena dalšími ostrovy (pouze její součást na katastru Kopčan už možná nebyla ostrovem), veligradská se rozkládala na výběžku Chřibů, pozvolna sestupujícím do říční nivy na ostrovy, přičemž největší chrám se nacházel na sadské výšině na druhém břehu Moravy. Proto mohla mít velké hlavní pohřebiště ve vyvýšené poloze Na Valách, které patrně navazovalo na nejstarší osídlení. Avšak systém dvorců na ostrovech, nebo možná méně formálně vydělených sídelních útvarů, je týž (srovnej kostely VI-X v Mikulčicích).

Přes veškeré nemalé problémy, at' už způsobené vývojem osídlení - na rozdíl od hradišt' Pohanska a Mikulčic je Uherské Hradiště živé město a na rozdíl od Starého Města jsou v něm středohradištní vrstvy uloženy mnohem hlouběji, nebo lidským faktorem - autory nezpracované zásadní výzkumy, neočíslované, a tudíž ztracené sbírkové předměty, a konečně i přes živelnou 
katastrofu se poznání tisícileté minulosti svatojiřských ostrovů obohacuje a posouvá kupředu. Naději do budoucna vzbuzuje současné dostačující personální obsazení archeologického pracoviště Slováckého muzea.

\section{Prameny}

GEISLER, M., 1994: Uherské Hradiště - hotel Inpost 1993. Archiv ÚAPP Brno, Nálezová zpráva č. j. 71/94. KALISZOVÁ, D., 1989: Dílčí nálezová zpráva z předstihového výzkumu na Otakarově ulici v Uherském Hradišti za roky 1987 a 1988 (8. a 9. sezóna). Archiv archeologického oddělení Slováckého muzea, Nálezová zpráva č. j. 404/96.

KOHOUTEK, J.-PROCHÁZKA, R., 1993: Uherské Hradiště, Hradební ul. - Růžová ul. (SPT Telecom). Archiv archeologického oddělení Slováckého muzea v Uherském Hradišti, Nálezová zpráva č. j. 581/98.

KOVÁČIK, P., 1997: Uherské Hradiště-Reduta. Závěrečná zpráva. Archiv archeologického oddělení Slováckého muzea v Uherském Hradišti, Nálezová zpráva č. j. 528/97.

PAVELČÍK, J., 1997: Uherské Hradiště-Reduta. Archiv archeologického oddělení Slováckého muzea v Uherském Hradišti, Nálezová zpráva č. j. 527/97.

SVITAVSKÁ-SVOBODOVÁ, H., 2011: Pylová analýza vzorků z archeologického výzkumu Uherské Hradiště, Otakarova ul. Posudek ke smlouvě 00/0161/2002, uložený v ARÚ AV ČR, Praha, v. v. i.

VITULA, P., 1994: Uherské Hradiště - dům manželů Arnoštových 1993. Archiv ÚAPP Brno, Nálezová zpráva č. j. 70/94.

ZEMAN, A., 2006: Výzkum archeologických materiálů z Mariánského náměstí v Uherském Hradišti. Zpráva uložená v ARÚ AV ČR, Praha, v. v. i.

\section{Literatura}

BIALEKOVÁ, D., 1988: Potrava živočíšneho pôvodu v pobedimskej sídliskovej ekuméne v 9. storočí, AR XL, 296-305.

BORZOVÁ, Z., 2016: Pol’nohospodárske náradie včasného stredoveku na Slovensku. Nitra.

CIBULKA, J., 1958: Velkomoravský kostel v Modré u Velehradu a začátky křest’anství na Moravě. Praha.

CULEK, M.-IVAN, A.-KIRCHNER, M., 1999: Geomorphologie der Talaue der March zwischen der Napajedla-Pforte und dem Zusammenfluss mit der Thaya. In: V. Internationale Tagungen in Mikulčice (Poláček, L.-Dvorská, J., edd.), 199-221. Brno.

ČIŽMÁŘ, M.-GEISLEROVÁ, K.-UNGER, J., 2000: Výzkumy - Ausgrabungen 1993-1998. Brno.

DRESLER, P.-VÁGNER, M., 2013: Geofyzikální průzkum Masarykova náměstí a lokalizace kostela sv. Jiří, Slovácko LIV, 155-164.

DRESLEROVÁ, G.-HAJNALOVÁ, M.-MACHÁČEK, J., 2013: Subsistenční strategie raně středověkých populací v dolním Podyjí. Archeozoologické a archeobotanické vyhodnocení nálezů z výzkumu Kostice-Zadní hrúd (2009-2011), AR LXV, 825-850.

FROLÍKOVÁ-KALISZOVÁ, D., 1990: Výsledky archeologického výzkumu v Uherském Hradišti v letech 1987-1988, Slovácko XXXI (1989), 115-121.

- 1991: Výzkum severního okraje velkomoravského ostrovního hradiska v Uherském Hradišti v letech 19871988, ŠZ AÚ SAV 27, 35-39.

- 2001: Keramika z Uherského Hradiště - technologický vývoj v 9. století. In: Konference Pohansko 1999. Archaeologia mediaevalis Moravica et Silesiana I/2000 (Měřínský, Z., ed.), 207-216. Brno.

- 2001a: Výzkum na Otakarově ulici v Uherském Hradišti - některé otázky vývoje velkomoravského hradiska. In: Velká Morava mezi východem a západem (Galuška, L.-Kouřil, P.-Měřínský, Z., edd.), 115-121. Brno.

- 2002: Parohový hrací kotouček, Slovácko XLIV (2002), 163-166.

- 2003: Olověný kř́žžek z Uherského Hradiště - Otakarovy ulice - Kleines bleiernes Kreuzchen aus Uherské Hradiště, Otakarova-Str., AH 28, 553-560. 
- 2004: Zvířecí kosti z 8.-10. století v Uherském Hradišti a jejich zpracování. Předběžná zpráva. In: Zborník na počest' Dariny Bialekovej (Fusek, G., ed.), 75-80. Nitra.

- 2007: Der Fluss Morava und der grossmährische Burgwall Uherské Hradiště. In: Siedlung, Kommunikation und Wirtschaft im westslawischen Raum (Biermann, F.-Kersting T., edd.), 299-306. Langenweissbach.

- 2009: Bronzový křižek z Uherského Hradiště - Das kleine Bronzekreuz aus Uherské Hradiště (Ungarisch Hradisch), AH 34, 563-574.

- 2009a: Zlomek skla z Uherského Hradiště, ŠZ AÚ SAV 45, 217-219.

- 2009b: Hrnce, hrnky, hrnečky... In: Archeologie doby hradištní v České a Slovenské republice. Archaeologia mediaevalis Moravica et Silesiana - Supplementum 2 (Dresler, P.-Měřínský, Z., edd.), 94-98. Brno.

- 2011: Nachgroßmährische Entwicklung der Agglomeration Uherské Hradiště - Staré Město. In: Der Wandel um 1000. Beiträge zur Ur- und Frühgeschichte Mitteleuropas 60 (Biermann, F.-Kersting, T.-Klammt, A., edd.), 209-214. Langenweissbach.

- 2011a: Korálky z Uherského Hradiště - příspěvek k poznání chemického složení časně středověkých skel, Historické sklo 5, 59-66.

GALUŠKA., L., 1990: Předběžné vyhodnocení výzkumu profánní kamenné architektury ve Starém Městě „Na Dědině“. In: Staroměstská výročí (Galuška, L., ed.), 121-136. Brno - Uherské Hradiště.

- 2006: Velkomoravská hradba v Uherském Hradišti-Rybárnách, AR LVIII, 486-510.

- 2008: Staré Město - Veligrad v období mezi zánikem Velké Moravy a založením Nového Velehradu Uherského Hradiště. In: Východní Morava v 10.-14. století (Galuška, L.-Kouřil, P.-Mitáček, J., edd.), 95-116. Brno.

- 2008a: K otázce raně středověkého opevnění ostrova sv. Jiří velkomoravské staroměstsko-uherskohradištské mocenské aglomerace, Acta Musei Moraviae, Scientes sociales XCIII, 115-127.

- 2009: K otázce osídlení Starého Města - Veligradu v době po zániku Velké Moravy. Mladohradištní keramika z lokality „Na Zahrádkách“ - Zur Frage der Besiedelung von Staré Město-Veligrad in der Zeit nach dem Untergang Grossmährens : jungburgwallzeitliche Keramik von der Fundstätte „Na Zahrádkách“, AH 34, 605-638.

- 2013: Hledání původu. Od avarských bronzů ke zlatu Velké Moravy - Search for origin. From Avar bronze items Great Moravian gold. Brno.

GEISLER, M., 1997: Uherské Hradiště, Velehradská ulice, č. p. 206, 128, 193, PV 1993-1994, 250.

- 2000: Doba hradištní. In: Výzkumy - Ausgrabungen 1993-1998 (Čižmáŕ, M.-Geislerová, K.-Unger, J., edd.), 59-63. Brno.

HANÁK, K., 1932: Po stopách zašlých hradisk na půdě staroslovanského Velehradu, Sborník velehradský NŘ 3, 5-9.

- 1933: Výroční zpráva o činnosti spolku, Sborník velehradský NŘ 4, 4-6.

- 1947: Vykopávky kostela sv. Jiří v Uh. Hradišti, Sborník velehradský NŘ 15, 6-10.

HAVLÍČEK, P., 1999: Die geologischen Verhältnisse in der Umgebung der Siedlungsagglomeration der grossmährischen Machtzentren Mikulčice und Staré Město. In: Probleme der mitteleuropäischen Dendrochronologie und naturwissenschaftliche Beiträge zur Talaue der March. V. Internationale Tagungen in Mikulčice (Poláček, L.-Dvorská, J., edd.), 181-197. Brno.

HRUBÝ, V., 1949: Objev kostela z 9. století na pohřebišti ve Starém Městě, AR I, 109-122.

- 1955: Základy kostela na staroslovanském pohřebišti ve Starém Městě „Na Valách“. Předběžná studie, PA XLVI, 265-306.

- 1955a: Staré Město - velkomoravské pohřebiště Na Valách. Praha.

- 1957: Osídlení ostrova sv. Jiří v době hradištní, SPFFBU E 2, VI, 75-87.

- 1965: Staré Město - velkomoravský Velehrad. Praha.

CHRZANOWSKA, W.-JANUSZKIEWICZ-ZALĘCKA, D., 2003: Tierknochenfunde aus der Vor- und Hauptburg des Burgwalls von Mikulčice. In: Studien zum Burgwall von Mikulčice V (Poláček, L., ed.), 122-138. Brno.

CHRZANOWSKA, W.-KRUPSKA, A., 2003: Tierknochenfunde aus dem Suburbium des Burgwalls von Mikulčice. In: Studien zum Burgwall von Mikulčice V (Poláček, L., ed.), 109-119. Brno.

KALISZOVÁ, D., 1990: 8. sezóna výzkumu na Otakarově ulici v Uherském Hradišti, PV 1987, 62-64. 
- 1991: 9. sezóna výzkumu na Otakarově ulici v Uherském Hradišti, PV 1988, 50-51.

KOHOUTEK, J.-PROCHÁZKA, R., 1997: Uherské Hradiště, Růžová-Hradební ulice, (okr. Uherské Hradiště), PV 1993-1994, 251-254.

KOVÁČIK, P., 1998: Příspěvek k historické topografii Uherského Hradiště, SPFFBU 47, M 3, $64-76$.

- 1999: Uherské Hradiště, Reduta, PV 40, 1997-1998, 374-377.

KRATOCHVÍL, Z., 1992: Zvířecí kostní materiál z jižního předhradí Břeclavi-Pohanska. In: Vignatiová, J., Břeclav-Pohansko II - slovanské osídlení jižního předhradí, 101-104. Brno.

MENOUŠKOVÁ, D., 2005: Archäologische Fundstätten und Funde im Nordteil des Unrtermarchtals III (Katastralgebiete Uherské Hradiště, Sady). In: Studien zum Burgwall von Mikulčice VI - Sonderdruck (Poláček, L., ed.), 459-538. Brno.

- 2006: Archeologické doklady osídlení katastru Uherského Hradiště, Slovácko XLVII (2005), 67-128.

- 2008: Uherské Hradiště, PV 49, 448-451.

- 2008a: Několik poznámek k topografii Uherského Hradiště. In: Východní Morava v 10.-14. stol. (Galuška, L.-Kouřil, P.-Mitáček, J., edd.), 229-236. Brno.

- 2013: Kostel a kaple sv. Jiří v Uherském Hradišti, Slovácko LV, 141-154.

- 2020: 70 let archeologických výzkumů středohradištních lokalit na Uherskohradišt'sku a současný stav poznání tzv. ostrova sv. Jiří, AH 45, 809-829.

MENOUŠKOVÁ, D.-DRESLER, P.-PELIKÁN, O., 2019: K průběhu a rozsahu destrukce kamenného objektu z Uherského Hradiště, Protzkarovy ulice, Slovácko LX (2018), 81-94.

MENOUŠKOVÁ, D.-VAŠKOVÝCH, M., 2005: Archäologische Fundstätten und Funde im Nordteil des Untermarchtals I - Uherské Hradiště, Sady. In: Studien zum Burgwall von Mikulčice VI - Sonderdruck (Poláček, L., ed.), 345-404. Brno.

MITÁČEK, J.-PROCHÁZKA, R., 2007: Město královské. In: Uherské Hradiště královské město na řece Moravě, 61-78. Uherské Hradiště.

OPRAVIL, E., 1998: Makrozbytky rostlinného původu z Uherského Hradiště a Starého Města, Slovácko XL, $115-119$.

POULÍK, J., 1955: Nález kostela z doby říše Velkomoravské v trati „Špitálky“ ve Starém Městě, PA XLVI, 307-351. - 1975: Mikulčice. Praha.

- 1988: K otázce vzniku předvelkomoravských hradišt', SlArch XXXVI, 189-216.

PROFANTOVÁ, N., 1992: Awarische Funde aus den Gebieten nördlich der awarischen Siedlungsgrenzen. In: Awarenforschungen II (Daim, F., ed.), 605-778. Wien.

- 1994: K nálezům ostruh z konce 7.-9. stol. v Čechách, PA - Supplementum 2. Mediaevalia Archaeologia Bohemica 1993, 60-85.

PROCHÁZKA, R., 1990: Charakteristika opevňovacích konstrukcí předvelkomoravských a velkomoravských hradišt' na Moravě. In: Pravěké a slovanské osídlení Moravy. Sborník k 80. narozeninám Josefa Poulíka, 288-306. Brno.

- 1999: Uherské Hradiště, Zelný trh č. 48/2, PV 39 (1995-1996), 465-467.

- 2009: Vývoj opevňovací techniky na Moravě a v českém Slezsku v raném středověku. Brno.

PROCHÁZKA, R.-HAVLÍČEK, P., 1996: Die slawische Besiedlung von Uherské Hradiště und ihr natürliches Milieu. In: Frühmittelalterliche Machtzentren in Mitteleuropa - mehrjahrige Grabungen und ihre Auswertung. Internationale Tagungen in Mikulčice 3 (Staňa, Č.-Poláček, L., edd.), 199-212. Brno.

PROCHÁZKA, R.-SNÁŠIL, R., 1983: Výzkumy v Uherském Hradišti v roce 1981, PV 1981, 62-64.

- 1984: Hlavní rysy lokační zástavby Uherského Hradiště ve 2. polovině 13. století. In: Urbes medii aevi, 45-52. Praha.

PROCHÁZKA, R.-SULITKOVÁ, L., 1984: Uherské Hradiště ve 13.-15. století. Uherské Hradiště.

SNÁŠIL, R., 1971: Funkce slovanského sídliště na ostrově sv. Jiří, SPFFBU E 16, 211-215.

- 1975: Průběh cesty mezi Uherským Hradištěm-Sady a Starým Městem v době hradištní, Slovácko 1974-1975 - Studie, 13-18.

- 1984: Specializovaná řemesla z ostrovního hradiska v Uherském Hradišti a jejich přínos pro další poznání společenské diferenciace 8.-9. století. In: XIII. mikulovské sympozium 1983, 152-161. Mikulov.

- 1986: Archeologie ve Slováckém muzeu, Slovácko XXVII (1985), 9-47. 
- 1987: Výsledky archeologických výzkumů Slováckého muzea za období 1981-1985, Slovácko XXVIII (1986), 33-46.

- 1987a: Pokus o nový výklad vzniku, vývoje a funkce velkomoravské aglomerace v oblasti uherskohradištské. In: XVI. Mikulovské sympozium 1986, 149-166. Mikulov.

- 1992: Zpráva o archeologických výzkumech a př́růstcích Slováckého muzea v roce 1991, Slovácko XXXIII-XXXIV, 117-129.

- 2001: „Capella Morauorum“ a „Templum sub titulo S. Clementis“, Slovácko XLII (2000), 177-194.

SNÁŠIL, R.-KRUŤA, T.-STLOUKAL, M., 1993: Výzkum v Uherském Hradišti-Rybárnách v roce 1986, část I - Materiály, Slovácko XXXV (1993), 115-147.

- 1995: Výzkum v Uherském Hradišti-Rybárnách v roce 1986, část II - Interpretace, Slovácko XXXVI (1994), 73-78

SNÁŠIL, R.-NOVOTNÝ, J., 1985: Výzkumy v Uherském Hradišti v roce 1983, PV 1983, 71-74.

SNÁŠIL, R.-PROCHÁZKA, R., 1981: Př́ípěvek k poznání velkomoravského střediska severní části dolnomoravského úvalu, Slovácko XXIII (1981), 9-58.

- 1984: Výzkumy v Uherském Hradiště v roce 1982, PV 1982, 63-65.

SVOBODOVÁ, H., 1990: Vegetace jižní Moravy v druhé polovině prvého tisíciletí, AR XLII, 170-230.

VAŠKOVÝCH, M., 2004: Archeologické výzkumy na katastru Starého Města, Slovácko XLV (2003), 109-155.

VITULA, P., 1997: Uherské Hradiště, Havlíčkova ul. 16, PV 1993-1994, 254-255.

ZÁBOJNÍK, J., 2005: Mikulčice - awarische Stadt. In: Kouřil, P., Die frühmittelalterliche Elite bei den Völkern des östlichen Mitteleuropas. Spisy AÚ AV ČR Brno 25, 101-114. Brno.

\section{Zusammenfassung}

Die Archäologie über Uherské Hradiště zur Zeit Großmährens - Grabungen, Menschen, Überschwemmungen (40 Jahre seit Aufnahme großflächiger Grabungen)

Uherské Hradiště entstand auf einigen Inseln, die durch pleistozäne Ablagerungen des Flusses March zwischen den Ausläufern des Marsgebirges (Chřiby) im Westen und dem Wisowitzer Bergland im Osten gebildet und im Holozän von mächtigen Überschwemmungslehmen überdeckt wurden (Havlíček 1999). Erst nach der Wende der Zeitrechnung begannen sich Böden darauf zu entwickeln, die Vegetation zu wachsen, und die Bedingungen wurden dazu geschaffen, die ihre Nutzung durch Menschen ermöglichten. Das Inselsystem ermöglichte einen Übergang über die March auf der die Region Brünn und das mittlere Waag-Gebiet verbindenden Trasse, gleichzeitig kreuzte sie sich hier mit der Nord-Süd-Ferntrasse zwischen dem Donaugebiet und dem Baltikum. Die strategische Lage des Ortes war der Grund, warum sich die Besiedelung des Gebietes von Staré Město spätestens ab Ende des 8. Jahrhunderts auch auf die Inseln ausbreitete und warum die gesamte Siedlungsagglomeration Staré Město - Uherské Hradiště (Veligrad) im 9. Jahrhundert zu einem der Zentren Großmährens wurde (Abb. 1, 2). Die Bezeichnung „St. Georgsinseln“ entstand nach der auf der südlichsten Insel in den schriftlichen Quellen vor 1257 belegten St. Georgskirche, denn der Name Uherské Hradiště bezieht sich erst auf die nach einem Siedlungshiatus im Jahr 1257 gegründete Stadt. Von den Inseln waren bis zum Jahr 1928, als dort ein Steigbügel karolingischen Typs entdeckt wurde, keine Funde bekannt, die älter als das Hochmittelalter waren. Im Jahr 1931 wurden zwei vergoldete Knöpfe (Gombíky) aus einem Grab in der Růžová-Str. geborgen, die dortige Kulturschicht wurde jedoch im Einklang mit den damaligen Kenntnissen ins 11. Jahrhundert datiert (übersichtlich Snášil-Procházka 1981, 12-13). Eine revolutionäre Änderung stellte sich vor 40 Jahren im Jahr 1979 ein. Damals wurde erstmals eine mittelburgwallzeitliche Kulturschicht in der Otakarova-Str. freigelegt und anschließend bei großflächigen Vorlaufgrabungen in der Otakarova-Str. (1979-1989) und auf dem Marienplatz (1980-1984) untersucht. Gleichzeitig verzeichnete man auch an verschiedenen 
Stellen in der Stadt bei Rettungsgrabungen und der Dokumentation von Liniengräben eine mittelburgwallzeitliche Schicht, stellenweise auch mit Mauerwerksresten oder Mörtelschollen (zusammenfassend Menoušková 2013, 142-145). Weitere wichtige Feststellungen lieferten kleinere Rettungsgrabungen an der Ecke der Straßen Hradební, Františkánská und Krátká Inpost, in der Havlíčkova-Str., an der Ecke der Straßen Hradební und Růžová - Telecom, in der Františkánská-Str. und im Hof der Redoute (Abb. 3). Die drei letztgenannten wurden bisher leider noch nicht bearbeitet.

In der Entwicklung der Besiedelung der St. Georgsinseln können wir zwei Haupthorizonte unterscheiden: einen älteren, als die Ränder der Inseln überschwemmt waren, während die Innenfläche der Insel wie es scheint hauptsächlich als Produktionsareal genutzt wurde; und einen jüngeren, als die Flächen der Inseln durch Verfüllung der toten Flussarme mit Abfall größer wurden und auf der Inseloberfläche eine ca. $50 \mathrm{~cm}$ mächtige Kulturschicht entstand, die von einer intensiven Besiedelung zeugt. Der ältere mittelburgwallzeitliche Horizont umfasst einen längeren, nur grob abgegrenzten Zeitraum, Spuren für die Anwesenheit von Menschen tauchen wohl ab Ende des 8. Jahrhunderts auf. In der Otakarova-Str. haben wir den Rand der Insel untersucht: quer durch die untersuchte Fläche zog sich von Osten nach Westen ein grabenartiges, stellenweise bis zu fünf Meter breites und ca. $50 \mathrm{~cm}$ tiefes Flussbett, das mit Stehwasser gefüllt war (Abb. 4). Was die Funde betrifft, war die Schicht neben dem in Fülle vorkommenden Scherbenmaterial sprichwörtlich mit Tierknochen übersät; neben unbearbeitetem Abfall tauchten Flechtstäbe, Ahlen und eine verzierte Scheibe von einem Geweih auf (Frolíková-Kaliszová 2002). Unter den Metallgegenständen ragt der Torso eines leicht gebogenen, wahrscheinlich landwirtschaftlichen Gerätes mit ungewöhnlich großen Abmessungen hervor; es wurde womöglich dazu verwendet, Reisig von Laubbäumen und Sträuchern abzuschlagen, um Futterlaub daraus zu machen (Abb. 5). Die zahlreichen Pfahlgruben im Flussbett sind wahrscheinlich Überreste von Pfählen, die über die sumpfige Fläche führende Stege und kleine Brücken trugen und laufend repariert und ausgetauscht wurden. Die Grenze zwischen dem ständig unter Wasser stehenden Gelände und dem Niveau gelegentlicher Überschwemmungen ist die Höhenlinie 175 m N.N., oberhalb der Höhenlinie 176 m N.N. lag die trockene Mitte der Insel, die eine Besiedelung möglich machte. Dies wurde am Marienplatz festgestellt, wo der ältere Horizont in den Verfüllungen der Siedlungsgruben erhalten blieb (Abb. 6), die sich durch eine dunklere Farbe von der Kulturschicht des jüngeren Horizontes unterschieden. Die Funde belegen die Tätigkeit einer Werkstatt oder von Werkstätten, die Knochen, Horn und Geweihe bearbeiteten, einer Schmiede und einer MetallgieBerei - in den Gruben M, O, P und S wurden drei Torsi von Hakensporen aus Bronze, der Torso eines Eisensporns und zwei awaroslawische Bronzebeschläge gefunden (Abb. 7). Die Bronzen zählen zum spätawarischen Kulturhorizont und waren wohl Teile eines Lagers für beschädigte, zum Umschmelzen bestimmte Bronzeprodukte. Das Ereignis kann in das Intervall zwischen Ende 8. Jahrhundert bis Anfang 9. Jahrhunder gelegt werden (Snášil 1984, 156-158; Profantová 1992, 691-692; 1994, 67-68; Galuška 2013, 91, 94). Einen bedeutenden Anteil des Fischfangs zur Ernährung der Bevölkerung belegen Funde von Angelhaken und Fischschuppen. Das Bett des toten Flussarms in der Otakarova-Str. war mit bis zu $80 \mathrm{~cm}$ starken Überschwemmungsschichten verschlammt. Dazu kam es durch den Zusammenschluss zweier zuvor getrennter Inseln. Dieses Ereignis bildet - die allerdings nicht genau datierte - Grenze zwischen dem älteren und jüngeren mittelburgwallzeitlichen Horizont. Das frühere Flussbett bildete danach eine Bodensenke, die offenbar nach jedem Regen verschlammte. Wahrscheinlich entstand auf ihr zwecks besserer Begehbarkeit ein mit Schotter verfüllter Balkenrost (Abb. 8).

Die Kulturschicht des jüngeren Horizontes wird charakterisiert durch ihren Gehalt an weißen Körnchen aus Kalk und Mörtel, ggf. aus Verputz, in dunklem Lehm. Die darin entdeckten eingetieften Objekte wurden durchweg durch Tätigkeiten der Kolonisten gestört, die im 13. Jahrhundert die Stadt gründeten. Die oberirdischen Objekte wurden offensichtlich (Abb. 9) vollständig zerstört (Abb. 10). Ein Beleg für das Christentum sind - neben Funden von kleinen Kreuzen - Steine mit daran klebendem Mörtel von den zerstörten, sehr wahrscheinlich kirchlichen 
Bauten. Diese Schlussfolgerung wird durch die Ergebnisse einer Analyse der Mörtel- und Verputzproben gestützt, durch die man Reste eines Farbanstrichs auf ihnen entdeckte. Man fand auch das Bruchstück eines Kalksteins mit waagerechter weißer Grundfläche und einem bauchigen, leicht rosanem oberen Teil. Das erhalten gebliebene Bruchstück eines Mauerwerks wurde bei der Grabung an der Baustelle für das Telecom-Gebäude freigelegt. Darauf, dass es (Abb. 11, 12) dabei um eine Kirche ging, deuten die Funde von mindestens drei Gräbern in der Umgebung hin. Wohl von einem abgerissenen Bauwerk stammende Steine tauchten in der Havlíčkova-Str. in einer Schicht vom Ende der Mittelburgwallzeit auf, weitere Torsi von Mauerwerken und Mörtelschollen wurden bereits in den achtziger Jahren bei der Dokumentation der Liniengräben auf dem Marien- und dem Masaryk-Platz entdeckt (Abb. 3:M). Unklar ist die Lage der St. Georgskapelle aus der Vorlokationszeit, die traditionell als ursprünglich großmährischer Bau angesehen und auf dem Masaryk-Platz unter den Fundamenten der ehemaligen gotischen St. Georgskirche gesucht wurde (Abb. 3:J). Eine weitere Kirche mit Gräberfeld wurde im Stadtviertel Rybárny entdeckt (Abb. 1; Snášil-Kruta-Stloukal 1993). Eine bemerkenswerte $8 \mathrm{~m}$ lange, mindestens $225 \mathrm{~cm}$ breite und $80-130 \mathrm{~cm}$ starke Aufschüttung von Trümmersteinen befand sich in der Protzkarova-Str. in der Nähe des beide Hauptinseln trennenden Wasserlaufs. Darin befanden sich vereinzelte Bruchstücke mittelburgwallzeitlicher Keramik.

Die Ergebnisse der osteologischen Analyse stellt die St. Georgsinseln an die Seite der Herrenhöfe in Pohansko oder der Burgwälle von Mikulčice und Pobedim: die meisten (ca. 50 \%) Knochen stammen von Schweinen, es folgt das Hausrind, ein wenig geringer vertreten sind kleine Wiederkäuer. In der Umrechnung auf die Menge des gewonnenen Fleisches sind Schwein und Rind freilich vergleichbar, während der Anteil an Ziegen und Schafen deutlich geringer ausfiel. Insgesamt 25 Hirschgeweihe von erlegten Tieren und nicht von Abwürfen stammende Hirschgeweihe sowie 20 Hörner des Auerochsen sind Überreste von Jagden der höchsten Gesellschaftsschichten (Frolíková-Kaliszová 1991, 37-38; 2004, 78).

Auf den St. Georgsinseln wurde bislang noch keine eindeutige Befestigungsanlage entdeckt. Von Gräbern begleitete Entdeckungen von Mauerwerk bedeuten offenbar, dass kleine Eigentumskirchen mit Familienfriedhof im Hof eines Adeligen oder eines Angehörigen der Fürstenfamilie auf den Inseln existierten. Die Datierung beider Horizonte bleibt lediglich eine anhand der Keramik vorgenommene relativ chronologische Datierung. Der jüngere Horizont mit Steinbauten wird auf Grundlage der Kenntnisse der historischen Entwicklung in die Blütezeit Großmährens gelegt, grob also in die Zeit zweite Hälfte 9. Jahrhundert bis Anfang 10. Jahrhundert, und die Besiedelung endet offenbar durch ein allmähliches Ausklingen in der ersten Hälfte des 10. Jahrhunderts.

PhDr. Drahomíra Frolíková-Kaliszová, Ph.D., Archeologický ústav AV ČR Praha, v. v. i., Letenská 4, 11801 Praha 1, Česká republika,frolikova@arup.cas.cz 
